WHC-EP-0433

\title{
Environmental Restoration Program Document Control Plan
}

L. M. Montgomery

Date Published

September 1993

Prepared for the U.S. Department of Energy Office of Environmental Restoration and Waste Management

\footnotetext{
(29) Westinghouse Hanford Company Richland, Washington 99352

Hanford Operations and Engineering Contractor for the

U.S. Department of Energy under Contract DE-AC06-87RL10930
}

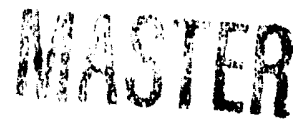

Approved for Public Release 
WHC-EP-0433

Document Title: Environmental Restoration Program Document Control Plan

Impact Leve1: $\quad 30$

Prepared by:

Q.M. Montqomery

L. M. Montgomery, speciadst

Environmental Records \& Information

Services

Approved by:

Approved by:

Approved by:

Approved by:

Approved by:

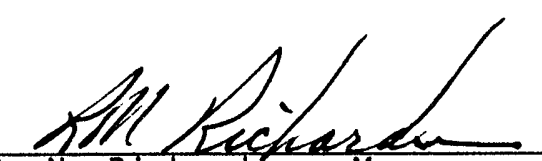

R. N. Richardson, Manager

Environmental Records \& Information Services

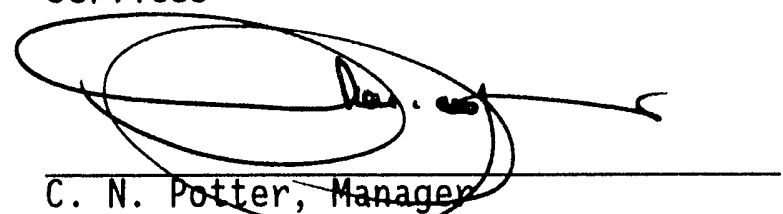

Documentation \& Retords Services

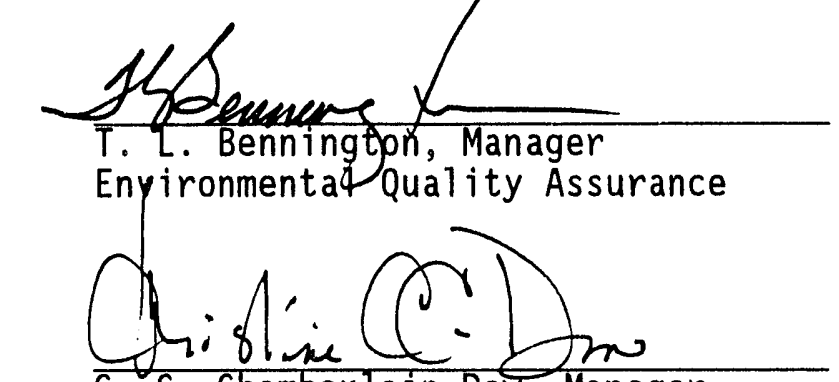

C. C. Chamberlain-Dow, Manager

Program Management Systems

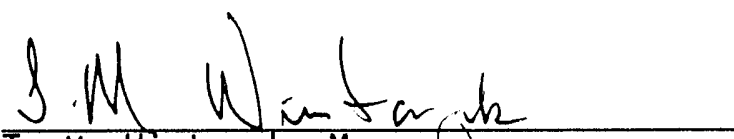

T. M. Wintczak, Managed

Environmental Restoration Program

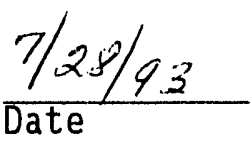

$7 / 28 / 93$

Date

$8 / 3 / 93$

Date

$8 / 23 / 93$

$\frac{8 / 24 / 93}{\text { Date }}$ 
WHC-EP-0433

This page intentionally left blank. 


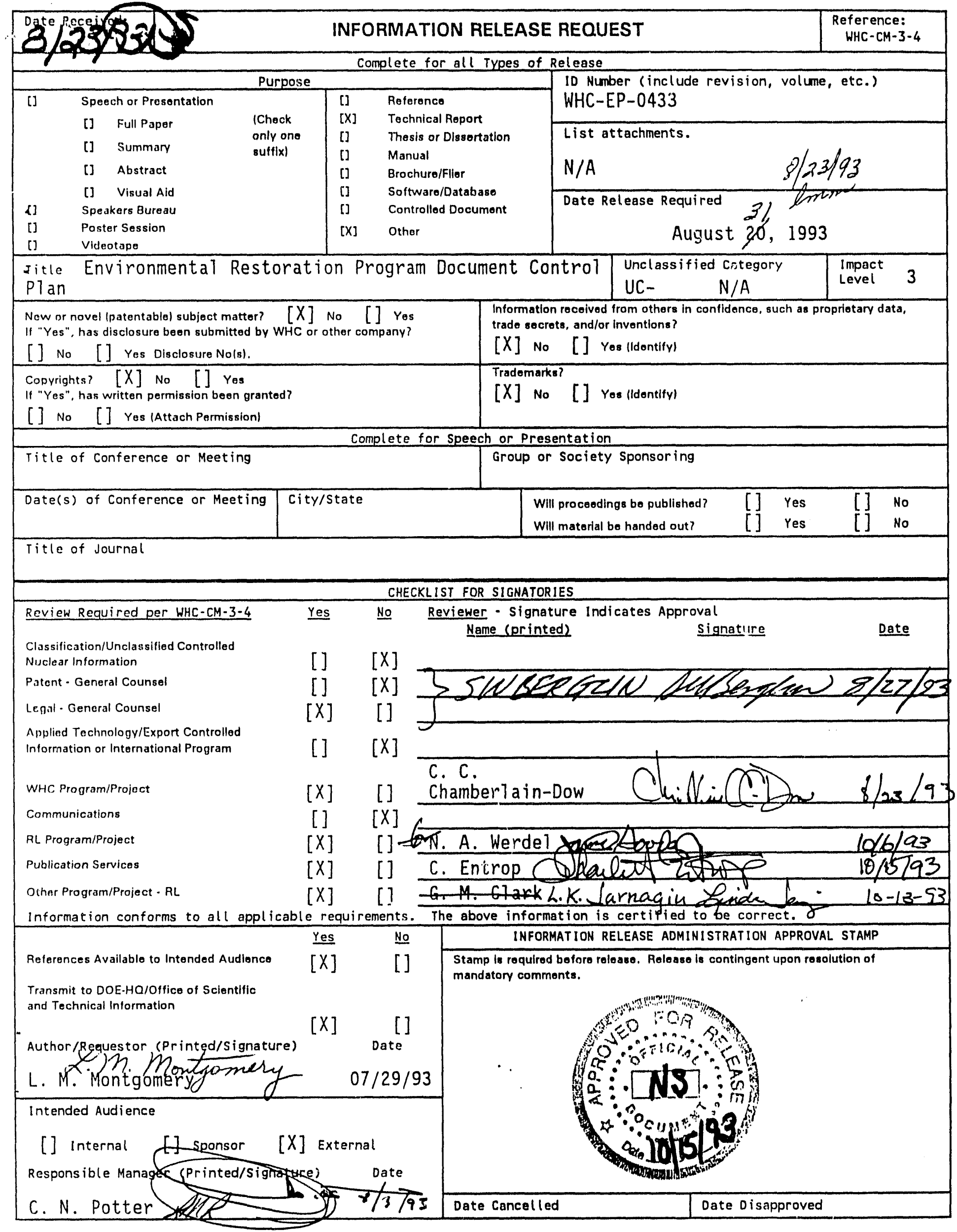




\section{CONTENTS}

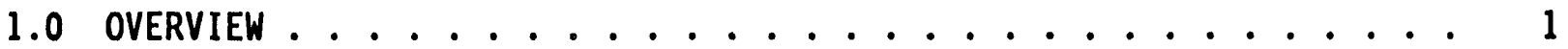

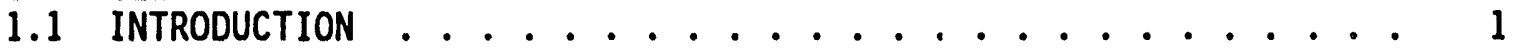

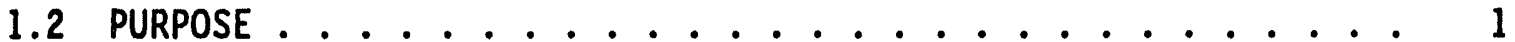

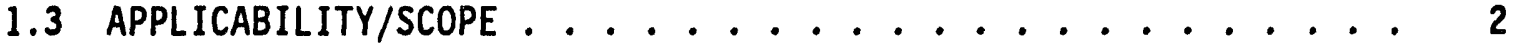

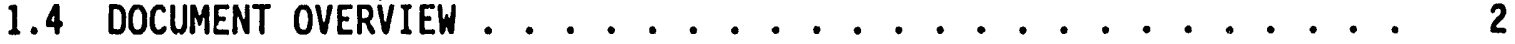

2.0 RESPONSIBILITIES . . . . . . . . . . . . . . 3

2.1 U.S. DEPARTMENT OF ENERGY, RICHLAND OPERATIONS DFFICE . . . . 3

2.2 REGULATORY AGENCIES ................. 3

2.3 U.S. ARMY CORPS OF ENGINEERS .............. 3

2.4 TRI-PARTY AGREEMENT UNIT MANAGERS .............. 3

2.5 WESTINGHOUSE HANFORD COMPANY ............. 4

2.5.1 ER Program Office ................ 4

2.5.2 Information Resource Management Department ....... 4

2.5.3 Environmental Quality Assurance ........... 6

2.5.4 Configuration Management .............. 6

2.5.5 Management Standards ............... 6

2.6 OTHER PERFORMING ORGANIZATIONS $\ldots \ldots 7$

3.0 DOCUMENT CATEGORIES AND PROCESSING REQUIREMENTS . . . . . . . 8

3.1 INTRODUCTION . . . . . . . . . . . . . 8

3.2 MAJOR ESTABLISHED DOCUMENT CONTROL SYSTEMS ........ 8

3.2.1 Types of Environmental Restoration Program Documents to be Controlled ................. 9

3.2.2 Performing Organization Operated Document Control Systems

3.3 CATEGORIZING ENVIRONMENTAL RESTORATION PROGRAM DOCUMENTS . . . 11

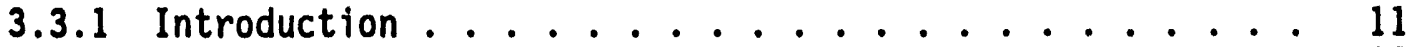

3.3.2 Administrative Record Documents ............ 12

3.3.3 Tri-Party Agreement Primary and Secondary Documents . . 13

3.3.4 Public Information Repository Documents ........ 14

3.3.5 Engineering Documents/Environmental Engineering Documents .................. 14

3.3.6 Formal Environmental Restoration Program Publications . 14

3.3.7 Environmental Field Logbooks and Other Controlled Notebooks.............. 15

3.3.8 Controlled Manuals .............. 15

3.4 DOCUMENT PROCESSING REQUIREMENTS . . . . . . . . . . 16

3.4.1 Creation/Preparation .............. 16

3.4.2 Review and Approval ............... 16

3.4 .3 Distribution .................. 17

3.4.4 Revision/Change Control .............. 17

3.4 .5 Storage and Retention ............. 18

3.4.6 Use of Environmental Restoration Program Controlled Documents ............... 19

3.4.7 Disposition of Environmental Restoration Program Documents ............... 19 
WHC-EP-0433

CONTENTS (cont.)

4.0 INFRASTRUCTURE AND INTERFACES ................... 19

4.1 ENVIRONMENTAL RESTORATION PROGRAM INFORMATION CENTER (EPIC) • • 19

4.2 COMPUTER RESOURCES .................. 20

4.3 INFORMATION SOURCES ................... 20

4.3.1 Hanford Technical Library ... . . . . . . . . 20

4.3.2 Environmental Resource Center ............ . 20

4.3.3 Environmental Data Management Center ......... . 21

4.3.4 Other Satellite Information Centers and Libraries . . . 21

4.3.5 Classified/Unclassified Document Control . . . . . . . 21

4.3.6 Configuration Management/Engineering Release System . . 21

4.3.7 Central Files .................. 22

4.3.8 Records Holding Area . . . . . . . . . . . . . 22

4.4 DOCUMENT CONTROL PLAN INTERFACES . . . . . . . . . . . . . . . 22

4.4.1 Environmental Restoration Program Information

Management System ................ 22

4.4.2 Environmental Restoration Program Records

Management System ................ 22

4.4.3 Environmental Restoration Program Configuration

Management System ................ 22

4.4.4 Environmental Restoration Program Information Matrix . . 22

5.0 DOCUMENT CONTROL PI.AN IMPLEMENTATION . . . . . . . . . . . . 23

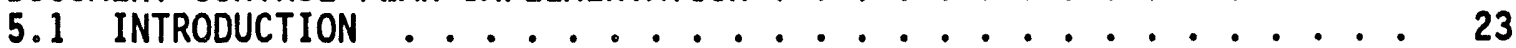

5.2 PERFORMING ORGANIZATION ROLES . . . . . . . . . . . . . 23

5.2.1 Environmental Restoration Program Office . . . . . . . 23

5.2.2 Information Resource Management Department .. . . . . 23

5.2.3 Environmental Records and Information Services . . . . . 24

5.2.4 Configuration Management .............. 24

5.2.5 Performing Organizations ............. . 24

5.3 IMPLEMENTING ACTIVITIES ................ 25

5.3.1 Procedures ................... 25

5.3 .2 Training ................. 26

5.4 ANNUAL REVIEW ....................... 27

6.0 REFERENCES .......................... . . 27

7.0 GLOSSARY . . . . . . . . . . . . . . . . 28

ACRONYMS AND ABBREVIATIONS . . . . . . . . . . . . . 28

TERMS AND DEFINITIONS ................... . . 29

APPENDICES

A ER PROGRAM DOCUMENT LIST . . . . . . . . . . . . . . . . A-i 
WHC-EP-0433

\section{ENVIRONMENTAL RESTORATION PROGRAM \\ DOCUMENT CONTROL PLAN}

\subsection{OVERVIEW}

\subsection{INTRODUCTION}

This Environmental Restoration (ER) Program Document Control P7an has been developed to comply with the document control system requirements of the U.S. Department of Energy, Richland Operations Office (RL), the Hanford Federal Facility Agreement and Consent Order (Tri-Party Agreement [Ecology et a1. 1992]), Westinghouse Hanford Company (WHC), and the ER Program.

One of the five components, or summary subprojects, of the ER Program is program management and support, which includes both management systems development and information and data management. Efforts within the management systems development area include the creation of a document control plan. This document control plan will provide a description and detailed methods for managing and implementing document control system requirements identified in the Environmental Restoration Program Quality Assurance System Requirements for the Hanford Site [(QASR) DOE-RL 1992a],

WHC has developed and established an overall document control system that governs the methods by which all WHC documents are generated, maintained, and disposed of. The ER Program performing organizations within WHC utilize the established WHC document control systems to the maximum extent possible. These systems are discussed in Chapters 3.0 and 4.0 of this plan. In addition, this plan describes the documents that require control within the ER Program and how they will be controlled.

\subsection{PURPOSE}

The purpose of this document control plan is to describe the following:

- The WHC Document Control Program as established by Management Policies (WHC-CM-1-1, MP 3.1), Management Requirements and Procedures (WHC-CM-1-3, MRP 3.21), and the Document Control and Records Management Manual (WHC-CM-3-5, Section 12)

- The applicable RL, Tri-Party Agreement, ER Program, and WHC document control requirements

- The Hanford Site document control systems applicable to the ER Program

- Organizational responsibilities for controlling documents

- Necessary steps for establishing new systems when additional controls are desired beyond the scope of the existing WHC and Hanford Site document control systems. 
WHC-EP-0433

This document control plan describes how the applicable document control requirements will be implemented for the ER Program and develops the criteria for identifying the appropriate requirements for each individual document related to ER Program work activities.

\subsection{APPLICABILITY/SCOPE}

This plan applies to all documents generated, used, or maintained by or for WHC performing organizations in support of ER-funded work activities on the Hanford Site. This encompasses all ER Program activities from the time needs are identified until the decisions are made to take action for all five components, or summary subprojects, of the ER Program.

The document control support functions addressed in this plan ensure the validity, accessibility, and integrity of documents that are used in the ER Program. All WHC organizations that perform activities under the purview of the ER Program are responsible for implementing the requirements of this plan that are applicable to their respective scopes of work.

\subsection{DOCUMENT OVERVIEW}

Chapter 2.0, "Responsibilities," identifies performing organization responsibilities. Also outlined are the responsibilities of $\mathrm{RL}$, the Washington State Department of Ecology (Ecology), the U.S. Environmental Protection Agency (EPA), and the U.S. Army Corps of Engineers (USACE).

Chapter 3.0, "Document Categories and Processing Requirements," establishes the criteria for properly identifying and handling ER Program documents to meet the requirements of WHC-CM-3-5.

Chapter 4.0, "Infrastructure and Interfaces," describes the basic facilities and resources at the ER Program level available. for implementation of this plan and describes the interfaces with related organizations and systems not described in this document.

Chapter 5.0, "Document Control Plan Implementation," describes the roles of ER Program performing organizations in the implementation of this $p l$ an and describes the major activities needed for effective implementation. plan.

Chapter 6.0, "References," lists documents referenced throughout this

Chapter 7.0, "Glossary," provides a list of acronyms and abbreviations and a list of terms and definitions applicable to this plan. 
WHC-EP-0433

\subsection{RESPONSIBILITIES}

Responsibilities of RL, Ecology, EPA, and the USACE are included for information only. Responsibilities of ER Program performing organizations within WHC are for compliance.

\subsection{U.S. DEPARTMENT OF ENERGY, RICHLAND OPERATIONS OFFICE}

The RL Environmental Restoration Division is responsible for all ER Program work, including the administration and compliance of document control activities and performance of periodic audits and surveillances of document and record practices.

\subsection{REGULATORY AGENCIES}

The regulatory agencies (EPA and Ecology) are responsible for complying with the document control activities outlined in the Tri-Party Agreement.

\subsection{U.S. ARMY CORPS OF ENGINEERS}

The U.S. Army Corps of Engineers (USACE) is considered an ER Program participant and, as such, is responsible for developing its own document control plan in support of Hanford Site ER Program work assigned to them by RL. The USACE is responsible for transferring Administrative Record (AR) information to WHC in compliance with the document control activities outlined in the Tri-Party Agreement.

The scope of work defined within the interagency agreement between the USACE and RL includes the following: engineering services, cost estimating, value engineering, technical and programmatic support, and review of RL documents; site-wide topographical and geographical surveys of monitoring wells and Resource Conservation and Recovery Act (RCRA) and Comprehensive Environmental Response Compensation and Liability Act (CERCLA) waste sites for placement in the Washington State Plane Coordinate System; management of assessment activities for selected RCRA and CERCLA past-practice operable units (OUs) from work plan generation through the Record of Decision (ROD); and management of remedial design and/or remedial action activities for assigned past-practice OUs from the ROD through completion. Work currently assigned to the USACE includes assessment activities for the 1100-EM-1 subproject and program management activities.

\subsection{TRI-PARTY AGREEMENT UNIT MANAGERS}

Tri-Party Agreement unit managers are responsible for identifying AR documents and ensuring that copies of these documents are provided to WHC. 


\subsection{MESTINGHOUSE HANFORD COMPANY}

WHC is an ER Program participant and performs ER Program activities as directed or assigned by RL. WHC is responsible for all ER Program work except for those activities assigned to the USACE. This includes assisting RL in the development of overall management systems for the ER Program. WHC ER Program performing organization responsibilities pertinent to document control activities are addressed in Sections 2.5.1 through 2.5.5 of this plan.

\subsubsection{ER Program Office} plan.

The following are WHC ER Program Office responsibilities regarding this

- Review and approve this plan. Developing and implementing this plan have been delegated by the ER Program office to the Information Resource Management Department, as identified in Section 2.5.2.1 of this plan.

- Direct performing organizations to comply with this plan.

- Identify documents that require control outside the scope of existing document control systems and that have not been previously identified as requiring control by the performing organizations.

- Submit ER Program documents generated by or for the ER Program Office to the document processing center at 740 Stevens Center, which is called the Environmental Restoration (ER) Program Information Center (EPIC).

\subsubsection{Information Resource Management Department}

The Information Resource Management (IRM) Department within WHC is responsible for establishing and managing the WHC document control program. In this capacity, IRM is responsible for the following.

- Manage and operate the EPIC for the ER Program Office.

- Operate the unclassified document control system (WHC-CM-3-5, Section 12.1).

- Operate classified document control system (WHC-CM-3-5, Section 12.2).

- Operate the Central Files and document processing/distribution system (WHC-CM-3-5, Section 12.4).

- Operate the document clearance program (Information Release Administration, WHC-CM-3-4).

- Operate the Uniform Publications System (Uniform Publications Systen, WHC-CM-3-6). 
Develop and maintain the WHC-CM-3-4, WHC-CM-3-5, and WHC-CM-3-6 manuals.

- Conduct management implementation reviews of document control activities and operations (WHC-CM-3-5, Section 1.1).

- Review and approve all WHC plans and procedures that establish or modify the company's document control systems.

- Review and approve this plan. This responsibility is shared by the ER Program Office (Section 2.5.1 of this plan) and the Environmental Quality Assurance organization (Section 2.5.3 of this plan).

- Provide assistance to line organizations on interpreting requirements, implementing document control systems, and resolving problems in a cost-effective manner.

2.5.2.1 Environmental Records and Information Sorvices. The Environmental Records and Information Services (ERIS) organization, within the IRM Department, is responsible for the following.

- Develop, maintain, and implement this plan for the ER Program Office.

- Establish, implement, and maintain the EPIC as the vehicle to bring the ER Program document control system into compliance with RL, Tri-Party Agreement, ER Program, and WHC document control requirements. EPIC will provide central (as well as satellite) document processing, retrieval, and disposition services.

- Operate the EPIC for all ER Program performing organizations.

- Assist in integrating applicable WHC and Hanford Site document control systems into the ER Program.

- Control documents, as requested, that are outside the scope of existing document control systems.

- Provide guidance and direction to performing organizations related to new or modified document control systems specific to the ER Program, which are outside the scope of existing document control systems.

2.5.2.2 Document Control Services. The Document Control Services organization, within tice IRM Department, is responsible for operating and managing Classified and Unclassified Document Control operations.

2.5.2.3 Documentation Support Services. The Documentation Support Services organization, within the IRM Department, is responsible for processing engineering drawing records; managing vendor information and specification 
files; managing engineering drawing and aperture card files; managing $16 \mathrm{~mm}$ and $35 \mathrm{~mm}$ microfilming operations; and managing Information Release Administration (IRA).

The IRA organization, within Documentation Support Services, is the IRM organization responsible for coordinating the review, approval, and clearance of unclassified documents. All documents identified in WHC-CM-3-4 must go through the document clearance process. IRA maintains a database and copies of completed document clearance forms. All documents included in an AR file are cleared for public release.

2.5.2.4 Publications Services. The Publications Services organization, within the IRM Department, is responsible for managing and operating the Uniform Publications System in accordance with WHC-CM-3-6.

2.5.2.5 Vault Services. The Vault Services organization, within the IRM Department, is responsible for operating and managing document processing/ distribution and document indexing and data entry support services; operating the 300 Area and 400 Area Quality Assurance (QA) vaults; and operating the Records Holding Area (RHA) at the 712 Building.

\subsubsection{Environmental Quality Assurance}

Environmental Quality Assurance is responsible for independent oversight of the document control program within the ER Program to ensure compliance with the Quality Assurance Manual (WHC-CM-4-2) and the QASR, for reviewing and approving this plan, and for overseeing compliance with this plan.

\subsubsection{Configuration Management}

The Configuration Management function, within the Engineering Services Department of WHC, is responsible for the following.

- Develop and maintain engineering practices contained in the standard Engineering Practices (WHC-CM-6-1) manual.

- Develop and maintain Configuration Management systems and procedures relative to identification, change control, status control, and verification of Configuration Management controlled documents.

- Operate engineering release stations in accordance with WHC-CM-6-1.

\subsubsection{Management Standards}

Management Standards is responsible for establishing standards for the controlled manual system (WHC-CM-1-3, MRP 2.16) and for ensuring the uniform preparation, review, and release of documents within the controlled manual system (Level I, II, and III manuals). 
WHC-EP-0433

\subsection{OTHER PERFORMING ORGANIZATIONS}

Each ER Program performing organization within WHC or under direct contract to WHC is responsible for complying with the requirements set forth in this plan. This includes other WHC organizations, other Hanford Site contractors, and subcontractors who have contractual obligations to WHC regarding ER work activities. It is the responsibility of the performing organizations to work with the procurement organizations to ensure these requirements are contractually imposed, as applicable, on subcontractors. It is also the responsibility of the performing organizations to impose these requirements, as applicable, on other Hanford Site contractors. Requirements may be imposed in Purchase Orders, Descriptions of Work, Statements of Work, Letters of Instruction, or other documents requesting services.

Each performing organization required to comply with any of the requirements identified in this $\mathrm{plan}$ is responsible for developing and maintaining procedures that ensure compliance.

Each ER Program performing organization (including other Hanford Site contractors and subcontractors who have contractual obligations to WHC regarding ER work activities) is responsible for documenting, in their implementing procedures, the following:

- Documents they are responsible for preparing, issuing, and/or distributing that require control (include those documents controlled by existing systems and those requiring new systems)

- Method(s) of control to be placed on each document requiring control

- Method(s) for document preparation, review, approval, issuance, and revision on each document requiring control

- Approved document control system (meeting the requirements identified in Chapter 3.0 of this document) for those documents that are outside the scope of the existing WHC document control systems, which may include submitting these documents to EPIC for processing.

- Method(s) to ensure maximum utilization of established document control systems and the EPIC

- Method(s) for submitting all plans and procedures that establish or modify document control systems to IRM for review and approval before issuance

NOTE: Specifically, IRM approval is limited to those procedures that demonstrate compliance with the WHC document control program requirements specified in WHC-CM-3-5, Section 12.

- Method(s) for providing IRM access to document files during the conduct of management implementation reviews as defined in WHC-CM-3-5, Section 1.1. 
WHC-EP-0433

\subsection{DOCUNENT CATEGORIES AND PROCESSING REQUIRENENTS}

\subsection{INTRODUCTION}

The IRM Department within WHC is responsible for implementing and operating the majority of systems controliing WHC generated documents (including federal agency publications prepared and/or generated by WHC). The requirements that are identified in this chapter are compiled from $W H C-C M-3-5$, WHC-CM-4-2, and the QASR (Part I, Section A, Criterion 5).

The requirements identified in this section are primarily intended for application on systems employed to control documents that are considered QA records. The majority of documents requiring control fall into this category; however, these requirements also should be applied to other documents when specifically required by the WHC ER Program office or IRM, when contractually imposed by WHC, or when imposed by WHC in documents requesting services. All documents (those considered $Q A$ and those not considered $Q A$ ) will be controlled to the degree necessary to comply with the requirements identified in this plan.

This Chapter describes the following:

- The major established document control systems supporting the ER Program

- The organizations responsible for operating the major established document control systems

- What types of documents are controlled by the major established document control systems

- Where the documents go to be controlled

- How to control documents that are not controlled by the major established document control systems.

\subsection{MAJOR ESTABLISHED DOCUNENT CONTROL SYSTEMS}

Major established document control systems that pertain to ER Program documents include the following:

- Classified and Unclassified Document Control (Sections 3.3.7 and 4.3.5 of this plan)

NOTE: The ER Program does not produce classified information or generate classified documents.

- Central Files document processing and distribution system (Sections 3.4 .5 and 4.3.7 of this plan)

- Records storage and retrieval (Sections 3.4.5 and 4.3. ${ }^{\circ}$ of this plan) 
WHC-EP-0433

Information Release Administration document clearance program (Section 3.4.2 of this plan)

- Uniform Publications System (Section 3.3.6 of this plan)

- Configuration Management engineering release system (Section 3.3.5 of this plan)

- Controlled Manual system (Section 3.3.8 of this plan)

- Administrative Record (AR) information system (Sections 3.3 .2 and 3.3.3 of this plan)

- Public Information Repository (PIR) information system (Section 3.3.4 of this plan).

\subsubsection{Types of Environmental Restoration Program Documents to be Controlled}

The following is a list of the types of ER Program documents that are required to be controlled. These document types include, but are not limited to:

- WHC Leve1 I, II, and III controlled manuals (WHC-CM-1-3, MRP 2.16, and Section 3.3 .8 of this plan)

- Engineering documents, including environmental engineering documentation (WHC-CM-6-1 and Section 3.3.5 of this plan)

- Documents published in accordance with WHC-CM-3-6 (Section 3.3.6 of this plan)

- Administrative Record (AR) documents listed in Section 9.0 of the Tri-Party Agreement Action Plan (Section 3.3.2 of this plan)

- Primary and selected secondary documents listed in Table 9-1 and Table 9-2 of the Tri-Party Agreement Action Plan (Section 3.3.3 of this plan)

NOTE: Many of the primary and secondary documents listed in the Tri-Party Agreement are published in accordance with WHC-CM-3-6 and are released into the engineering release system to assure the appropriate level of control. Revisions

\footnotetext{
1"Action Plan for Implementation of the Hanford Consent Order and Compliance Agreement Between U.S. Environmental Protection Agency, and State of Washington Department of Ecology as Amended September 1991 and August $1992, "$ in Ecology et al. 1992.
} 
to the primary and secondary documents are accomplished in accordance with the methods outlined in Section 9.3 of the Tri-Party Agreement Action Plan.

- Public Information Repository (PIR) documents listed in Table 1 of the Community Relations Plan for the Hanford Federal Facility Agreement and Consent Order (CRP) (Ecology et al. 1990) (Section 3.3.4 of this plan)

- Other documents, such as work instructions, that contain requirements in which failure to comply could adversely affect compliance with higher-tier documents.

\subsubsection{Performing Organization Operated Document Control Systems}

ER Program performing organizations may choose to impose additional controls on ER documents being controlled in cases where existing systems do not meet their needs. If controls desired exceed those offered by the established systems identified in Section 3.4 of this plan, the performing organization is responsible for controlling the document (or identifying the organization performing the service) in accordance with the requirements identified in this plan. These additional controls must be identified in the performing organization's impleme tting procedures, which must be reviewed and concurred with by IRM before implementation.

All systems used for controlling technical working level procedures, instructions, etc., must comply with the requirements in WHC-CM-3-5, Section 12.5. The requirements of Section 12.5 do not apply to procedures controlled by Management Standards, work packages controlled by the Job Control System (WHC-CM-8-8), or desk instructions.

The ERIS organization, as a performing organization that operates the EPIC, controls a few ER Program documents that are outside the scope of the major existing document control systems. At this time, these documents include:

- Administrative Record Index (RL-TPA-90-0002) (DOE-RL 1990a)

- Controlled distribution of the Tri-Party Agreement

- Public Information Repository (PIR) Handbook (RL-TPA-90-0003) (DOE-RL 1990C).

This service of controlling ER Program documents outside the scope of the existing document control systems can be expanded to include other ER Program documents, as needed. However, the major established document control systems should be used to the maximum extent possible by all ER Program performing organizations. 
WHC-EP-0433

\subsection{CATEGORIZING ENVIRONMENTAL RESTORATION PROGRAM DOCUMENTS}

\subsubsection{Introduction}

Documents generated for the ER Program are prepared in a variety of formats and issued with a variety of controls. Categorizing ER Program documents includes determining the appropriate document type for the various kinds of documents and ensuring selection of the right system within which to publish documents. Overlaps exist between scime of these control systems. For example, Supporting Documents are prepared and produced in accordance with WHC-CM-3-6, distributed and revised in accordance with WHC-CM-6-1, and archived in accordance with WHC-CM-3-5.

Document control is required throughout the ER Program, including documents generated during or as a result of investigation and remediation engineering work activities for treatment, storage, and disposal (TSD) unit permitting or closure processes and CERCLA and RCRA past practices processes required by the Tri-Party Agreement. Those ER Program documents that represent the final documentation of key data and reflect decisions on how to proceed will be treated as primary documents as described in Section 9.0 of the Tri-Party Agreement Action Plan. Those ER Program documents that represent an interim step in a decision-making process or are issued for information only and do not reflect key decisions will be treated as secondary documents as described in Section 9.0 of the Tri-Party Agreement Action Plan. Those documents include, but are not limited to, operable unit work plans, remedial investigation reports, aggregate area management stı!dies, and feasibility study reports. Most primary and secondary documents are released into the engineering release system to assure the appropriate level of control. See Section 3.3.3 of this plan.

Some ER Program documents also will be categorized as Public Information Repository (PIR) documents in accordance with the CRP and Section 3.3.4 of this plan. Only those documents that request public input or involve the public are placed in the PIRs (i.e., public review copy and final approved version). Most, but not all, PIR documents also are considered AR documents.

All other ER Program documents not identified in the Tri-Party Agreement Action Plan andior the CRP will be categorized in accordance with

Sections 3.3.5 through 3.3.8 of this plan. These documents include, but are not limited to, conceptual phase documents, functional requirements or functional design criteria documents, conceptual design reports, and definitive design documents issued during or as a result of remediation engineering activities required to meet $\mathrm{RL}$, ER Program, or WHC requirements.

All ER Program performing organizations shall use the guidelines for determining document type contained in WHC-CM-3-6, Section PS-1-02, to determine the appropriate document type for the various kinds of documents generated by the ER Program and to ensure that these documents are properly controlled. These guidelines do not require that any existing documents be reformatted or moved to another document control system. Existing documents should be evaluated against this guidance and, if necessary, moved to the correct control system when they are revised. 
A list of typical ER Program documents or document types has been compiled for use by ER Program performing organizations to assist them in categorizing and controlling specific ER Program documents (Appendix A). This list identifies the document control systems through which many existing ER Program documents have been processed and is designed to provide guidance to determine how to issue specific program documents.

\subsubsection{Administrative Record Documents}

An Administrative Record (AR) document is a document containing information that is considered or relied upon in arriving at a record of decision or in issuance of a permit. These documents are shown in Table 9-3 of the Tri-Party Agreement. Action Plan.

In addition to those documents listed in Table 9-3, the Tri-Party Agreement unit managers will determine what additional documents should be included in the AR files. This may include validated sampling and analysis results, supporting technical studies and analyses, inspection reports and follow up analyses, and other documents. The unit managers decide at least monthly what documents issued during the previous month are appropriate for inclusion in the AR files.

Many of the AR documents are categorized as primary or secondary documents in accordance with Section 9.0 of the Tri-Party Agreement Action Plan and Section 3.3.3 of this plan. For each primary document identified for inclusion in the AR, the AR files shall include:

- All drafts submitted to the regulatory agencies for review and/or approval

- Written comments from the support regulatory agency to the lead regulatory agency

- Written comments from the lead regulatory agency to RL (to include Notice of Deficiency on a Permit Application)

- RL written responses to comments received from the lead regulatory agency

- Final document and any subsequent revisions

- Drafts that are submitted for public comments.

For each secondary document identified for inclusion in the AR, the AR files shall include:

- Final document and any subsequent revisions

- Written comments from the support regulatory agency to the lead regulatory agency, if provided

- Written comments from the lead regulatory agency to RL, if provided 
RL written responses to comments received from the lead regulatory agency.

Drafts of documents that are undergoing internal review (within EPA, Ecology, RL, and WHC) will not be included in the AR files.

Primary and secondary documents are only included in the AR files if they are considered or relied upon by the lead regulatory agency in reaching a record of decision or permit/permit modification. In addition to those primary and secondary documents that meet the criteria for being included in the AR files, many other types of documents also are included in the AR files. These other documents are typically generated from sources other than Hanford Site contractors. Examples of these other documents include regulatory agency correspondence, public comments, regulatory agency responses, studies done by independent organizations, guidance documents, public meeting minutes, and many others.

A11 AR documents issued by or for the ER Program shall be included in the $A R$ files maintained by WHC for RL.

\subsubsection{Tri-Party Agreement Primary and Secondary Documents}

A11 ER Program documents described in the Tri-Party Agreement Action Plan, Section 9.0, must be categorized as either primary or secondary documents. All primary and secondary documents containing information considered in arriving at a record of decision or issuance of a permit or listed in Table 9-3 of the Tri-Party Agreement Action Plan are included in AR files maintained by WHC for RL.

Primary documents are those that represent the final documentation of key data and reflect decisions on how to proceed. The Tri-Party Agreement Action Plan, Table 9-1 provides a listing of primary documents. Examples of primary documents include work plans, remedial investigation Phase II reports, feasibility study reports, closure plans, etc.

Secondary documents are those that represent an interim step in a decision-making process, or are issued for information only, and do not reflect key decisions. The Tri-Party Agreement Action Plan, Table 9-2 provides a listing of secondary documents. Examples of secondary documents include Hanford Site operable unit and waste management reports, remedial investigation Phase I reports, quarterly progress reports, sampiing and data results, etc.

Many of the primary and secondary documents listed in the Tri-Party Agreement are published in accordance with WHC-CM-3-6 and are released into the engineering release system to assure the appropriate level of control (Section 3.3.5 of this plan). Revisions to the primary and secondary documents are accomplished in accordance with the methods outlined in Section 9.3 of the Tri-Party Agreement Action Plan and Section 3.4.4 of this plan. 
WHC-EP-0433

\subsubsection{Public Information Repository Documents}

To support Tri-Party Agreement requirements for providing information to the public, certain documents are submitted to the Public Information Repositories (PIRs). Table 1 in the CRP contains a listing of documents to be placed in the PIRs. Most, but not all, primary and secondary AR documents are included on this listing (Section 3.3.3 of this plan). This information may include remedial investigation work plans, design work plans, transcripts and summaries from public meetings and workshops, copies of the Tri-Party Agreement, and related documents.

\subsubsection{Engineering Documents/Environmental Engineering Documents}

The five categories of engineering documents are: drawings, specifications, vendor information, supporting documents, and selected types of environmental engineering documentation. Engineering documents are controlled in accordance with WHC-CM-5-1 as follows:

- Drawings (assigned numbers, prepared, released, and revised in accordance with EP-1.3, EP-1.5, and EP-2.2)

- Specifications [numbered, prepared, released, and revised (singleuse specifications only) in accordance with EP-1.2 and EP-2.2]

- Vendor information (assigned numbers and controlled in accordance with EP-3.3)

- Supporting documents (numbered, prepared, released, and revised in accordance with EP-1.12 and EP-2.2)

- Environmental engineering documents include environmental work plans, feasibility studies, aggregate area management studies, and remedial investigation reports. These documents are prepared according to the applicable federal agency publication specifications, are numbered and published in accordance with WHC-CM-3-6 (PS-3-01), are reviewed for public release in accordance with WHC-CM-3-4, and are released into the engineering release system and revised in accordance with WHC-CM-6-1 (EP-1.6, EP-1.7, and EP-2.2). Environmental engineering documents may be released in draft and/or final form. All environmental engineering documents for the ER Program are to be submitted to a ConfigurationManagement-operated engineering release station for processing.

All documents released through the engineering release system are $Q A$ records, and the processing of the record is performed for the author or initiating organization at the time of creation (release into the engineering release system) by Configuration Management release station personnel.

\subsubsection{Formal Environmental Restoration Program Publications}

Formal ER Program publications are published through the Uniform Publications System, which provides uniform methods for identifying, 
preparing, distributing/transmitting, reporting, tracking, and archiving unclassified scientific, technical, engineering, and administrative information using unique document numbering systems.

The Publication Services organization, within the IRM Department, assists authors in securing unique identification numbers appropriate to the type of document being issued. Guidance for determining the appropriate document type is found in WHC-CM-3-6, Section PS-1-02.

Publications Services also provides editing and document coordination services to authors of all types of documents. Editing services are required for the following formal ER Program publications:

- Speech/Article publications

- External publications

- Federal agency publications

Each of these document types is described in detail in WHC-CM-3-6, as are the following additional document types:

- Miscellaneous reports

- Sponsor-Limited publications

- Supporting documents

- Controlled manuals

- Internal publications

\subsubsection{Environmental Field Logbooks and Other Conitrolled Notebooks}

Field logbooks used during environmen ial field investigation work activities performed by ER Program performing organizations or subcontractors are managed in accordance with the Environmental Investigations and Site Characterization Manual (WHC-CM-7-7, EII 1.5). The EPIC provides personnel to assign, track, maintain, protect, and disposition field logbooks assigned to individuals in ER Program performing organizations.

Other controlled notebooks, such as laboratory notebooks used for recording scientific or technical information, are managed in accordance with WHC-CM-3-5, Section 12.1.

\subsubsection{Controlled Manuals}

Management Standards is responsible for establishing the standards for the control manual system and for ensuring the uniform preparation, review, and release of documents within the control manual system, in accordance with WHC-CM-1-3, MRP 2.16. The document types controlled by the Management Standards operated system outlined in WHC-CM-1-3 include:

- Level I Controlled Manuals

- Level II Controlled Manuals

- Level III Controlled Manuals. 
All ER Program controlled manuals shall be developed and issued through WHC Management Standards in accordance with WHC-CM-1-3, MRP 2.16, and distributed by Unclassified Document Control. Controlled manuals that generate documents will have to provide users with the information they need to schedule these documents for retention or disposal properly and in accordance with the requirements of the Environmental Restoration (ER) Program Records Management Plan (Montgomery 1992).

The controlled manual system is intended to contain company policies, charters, and administrative manuals containing requirements and procedures governing work in specific functional or topical areas (engineering, quality assurance, safety, etc.).

\subsection{DOCUMENT PROCESSING REQUIREMENTS}

\subsubsection{Creation/Preparation}

All ER Program documents shall be prepared in accordance with the format and content requirements applicable to the type of document being generated, as determined in accordance with Section 3.3 of this plan.

The preparation, review, issuance, and change of instructions, procedures, plans, and drawings that specify quality requirements or prescribe activities affecting quality shall be controlled to ensure that correct documents are available to the user. Such documents, including changes thereto, shall be revtewed for adequacy, completeness, or correctness before approvai.

\subsubsection{Reviow and Approval}

All ER Program documents shall be reviewed and approved in accordance with the requirements applicable to the type of document being generated. Procedures controlling document reviews shall identify organizations authorized to perform such reviews. The assignment of reviewers within those organizations is the responsibility of the cognizant manager.

Review of controlled documents may be accomplished by written comment or in formal document review meetings. In elther case, reviews shall be documented by maintaining comment and disposition records, review completion sign-off records, or meeting minutes.

Procedures for the review, approval, and issuance of program documents, and changes thereto, shall be established to ensure that technical adequacy and inclusion of appropriate QA requirements are included before implementation. The $Q A$ organization shall review and concur with the $Q A$ aspects of ER Program documents. These documents also shall be reviewed for technical adequacy by an individual or organization other than the person who generated the document, but who has a technical understanding of the pertinent issues and relevant documents. The submitting organization is obligated, as requested, to provide reviowing organizations access to pertinent background information upon which to base its approval (or rejection). 
For documents important to safety, quality, or environmental protection (except for controlled manuals), for the initial distribution or modification (changes or revisions), the impact level and review and approval requirements shall be determined in accordance with the criterla in WHC-CM-1-3, MRP 5.43 . For controlled manuals use MRP 2.16.

The IRA organization, within the IRM Department, is responsible for coordination of the review, approval, and distribution of unclassified information. This includes all documents identified in WHC-CM-3-4.

\subsubsection{Distribution}

Distribution control is a task typically performed by service organizations. Distribution control includes the following:

- Controlled distribution

- Copy control distribution

- General distribution

- Uncontrolied distribution.

These distribution methods are described in WHC-CM-3-5, Section 12.1 and Section 12.4. In general, the type of document generated will determine the distribution method used.

Unclassified Document Control distributes unclassified controlled documents, including controlled manuals, controlled notebooks, and other selected controlled documents. Vault Services distributes environmental engineering documents processed through Configuration Management and/or Publication Services.

Documents generated by or for the ER Program may be distributed by the performing organizations or by service organizations in accordance with the requirements applicable to the type of document generated, as determined in accordance with Section 3.3 of this plan. The distribution method and responsible organization shall be identified in performing organization implementing procedures.

\subsubsection{Revision/Change Control}

Revision control is a task typically performed by service organizations. Revision control includes both direct revision and/or page change revisions.

Changes may be incorporated in controlled documents by revising the entire document or by revising individual pages. The current revision status shall be readily evident on the document's revision status page. When an entire document is revised, all pages will reflect a common revision control designator. When only individual pages are revised, the revision control designator is only required on the revised pages.

The existing WHC manuals, which identify the specific document types referenced throughout this plan, also identify the change control requirements for the specific documents. 
Changes to Tri-Party Agreement primary or secondary documents shal1 follow the process identified in Section 9.3 of the Tri-Party Agreement Action Plan. The process followed by the ER Program performing organizations to change primary or secondary documents shail be identified in their implementing procedures (e.g., WHC-CM-7-7, EII 1.9).

Except for baseline documents, changes to ER Program documents shall be controlled, reviewed and approved as follows.

3.4.4.1 Major Changes. Changes to documents (other than those defined below as minor changes) are considered "major changes" and shall be revlewed and approved by the same organizations that performed the original review and approval, unless other organizations are specifically designated.

3.4.4.2 Minor Changes. Minor changes to documents, such as editorial corrections, shall not require the same review and approval as the original documents. The type of minor changes that do not require such a review and approval, and the persons who can authorize such a decision, shall be clearly dellneated.

Changes to technical, cost, scope, or schedule baseline documents for the ER Program shall be identified, evaluated, and dispositioned in accordance with change control procedures currently being developed for the ER Program.

\subsubsection{Storage and Retention}

Coptes of ER Prcyram documents are stored at the EPIC located in the 740 Stevens Center Bullding and at Central Files located in the 3706 Building in the 300 Area. The EPIC contains reference copies of ER Program documents, including microfilm reels of AR documents. Central Files contains the offictal record copies of ER Program documents.

Reference coples of ER Program documents also are available at satellite records centers and 1 ibraries operated for ER Program performing organizations to support work activitles at those locations (Section 4.3 .4 of this plan).

The Vault Services organizat on, within the IRM Department, is responsible for the control, accountalifity, and retrieval of documents stored and maintained in the Central flles facility. The types of documents controlled by the Central Files operated system include documents that are categorized as QA records stored in the Central Files facility and other documents stored in the facility. All documents released into the engineering release system may be obtained from any Configuration-Management operated engineering release station.

A11 ER Program documents shall be retained in accordance with ER Program performing organization's approved Records Inventory and Disposition Schedules (RIDS) and in accorfance with the requirements of WHC-CM-3-5 and Chapters 3.0 and 4.0 of the ER Program Records Management Plan (Montgomery 1992). 
WHC-EP-0433

\subsubsection{Use of Environmental Restoration Program Controlled Documents}

When documents are required for a specific work activity, procedures controlling the work shall require that, before starting work, approved copies of the applicable documents, and changes thereto, are distributed to and used at the location of the prescribed activity.

obsolete, void, or superseded documents shall be removed from work areas and replaced, when applicable, with revised documents. ihis requirement is 1 imited to documents controlling or directing work activities, is not intended to be applied to reference files, and may be accomplished through document recall/revision notification for controlled distributions. For uncontrolled distributions, the responsibility must be established for all employees to verify the status of each document against a revision control database before its application in controlling or directing work activities.

\subsubsection{Disposition of Environmental Restoration Progran Documents}

All ER Program documents shall be dispositioned in accordance with ER Program performing organization's approved RIDS and in accordance with the requirements of WHC-CM-3-5 and Chapters 3.0 and 4.0 of the ER Program Records Management Plan (Montgomery 1992).

\subsection{INFRASTRUCTURE AND INTERFACES}

\subsection{ENVIRONMENTAL RESTORATION PROGRAM INFORMATION CENTER (EPIC)}

The EPIC provides a centralized location and satellite locations for the processing and retrieval of ER Program information (data, documents, and records) and utilizes existing company systems to control selected ER Program documents.

The EPIC and its satellite records centers are responsible for ensuring or verifying that ER Program documents received are processed through approprlate WHC document control systems and for retaining a copy of applicable documents to meet other Program or regulatory requirements.

This facility provides a "one stop shop" for processing documents and will provide the following:

- A centralized facility with avallable hardware and software to provide complete services for document control, including environmental engineering document release, duplication, distribution, etc. 
WHC-EP-0433

Satellite facilities to support work activities but staffed and equipped only to perform those functions necessary for work at that location, such as requests requiring expedient processing

- Established procedures to direct the flow of documents within the EPIC and satellite facilities, to identify responsibilities and interfaces between EPIC personnel, and to identify interfaces between the EPIC and existing document control systems and other ER Program performing organizations

- Training for EPIC and functional organization personnel in the requirenients of this plan.

\subsection{CONPUTER RESOURCES}

The EPIC will develop, establish, and maintain a single "master" database to index and status ER Program documents. The master database will provide the status of documents during processing and the location of the documents within the applicable document control systems. The master database also will ensure that specific ER Program documents can be extracted for the AR files, the PIRs, the ER Program project files and other files management systems.

\subsection{INFORMATION SOURCES}

Copies of ER Program documents and other Hanford Site documents are available from the following information sources.

\subsubsection{Hanford Technical Library}

The Hanford Technical Library, operated by Pacific Northwest Laboratories and located in the 300 Area, has copies of many historical Hanford Site documents.

\subsubsection{Environmental Resource Center}

The Environmental Resource Center reference library contains the following types of reference documents:

- Federal, state, and local guidance documents

- DOE orders

- Hanford Plant Standards

- Applicable WHC controlled manuals

- Hanford Site work plans (identified in the Tri-Party Agreement)

- Hanford Site permit applications (identified in the Tri-Party Agreement) 
WHC-EP-0433

Miscellaneous Hanford Site and other DOE site documents

- Hanford Site maps and photographs.

\subsubsection{Environmental Data Management Center}

The main focus of the Environmental Data Management Center (EDMC) files management system is the collection of information that has been sent to or received from one of the agencies participating in the environmental restoration of the Hanford Site. The EDMC files management system contains documents related to operable units, TSD units, interim response actions, and expedited response actions (Tri-Party Agreement and AR documents).

\subsubsection{Other Satellite Information Centers and Libraries}

Reference copies of ER Program documents also are available at satellite records/information centers and libraries operated for ER Program performing organizations to support work activities at those locations. The satellite centers provide interim support to the ER Program functional organizations by organizing field files, setting up libraries, cata?oging data, managing oneof-a-kind information, and transmitting completed $Q A$ records and other record material to the Records Holding Area (RHA) as specified by organizational RIDS approved by IRM. The EPIC also will have access to the information databases maintained by these satellite centers.

Existing satellite ER Program centers include the Decommissioning Engineering records center, the Environmental Restoration Engineering records center, the Environmental Field Services records center and library, the Hanford Geotechnical Sample Library, and the Geosciences Technical Information Center.

\subsubsection{Classified/Unclassified Document Control}

Controlled and uncontrolled (information) copies of ER Program controlled manuals, controlled notebooks, and selected unclassified documents requiring copy control are available from Unclassified Documerit Control.

If it becomes necessary to retrieve classified documents for use by $E R$ Program performing organizations, copies are available from Classified Document Control in accordance with applicable requirements, e.g., need-toknow and appropriate clearance.

\subsubsection{Configuration Management/Engineering Release System}

Configuration Management is responsible for the release, processing, and control of ER Program engineering documents ard environmental engineering documentation. The Configuration-Management operated engineering release work stations can provide the current status of any engineering document. 


\subsubsection{Central Files}

Official record coples of ER Program documents are maintained at Central Files. In addition, other WHC engineering and QA documents are available at Central files. Documents can be reviewed at Central Files, or coples can be requested.

\subsubsection{Records Holding Area}

The Vault Services organization, within the IRH Department, operates the Records Holding Area (RHA) for the Hanford Site. Historical Hanford Site documents that have been sent to the RHA by prior Hanford Site contractors [such as Atlantic Richfield Hanford Company, Rockwell Hanford Operations, Douglas United Nuclear, UNC Nuclear Industries, and others] can be made available to ER Program performing organizations on a need-to-know basis.

\subsection{DOCUNENT CONTROL PLAN INTERFACES}

\subsubsection{Environmental Restoration Program Information Management System}

The ER Program document control system is a subset of the ER Program Information Management System currently being developed by RL. The Information Management System is defined in terms of interrelated functional areas, including document control. Document control support functions ensure the validity, accessibility, and integrity of documents that are used in the ER Program, included in records, or released to the public.

\subsubsection{Environmental Restoration Progran Records Management System}

The ER Program records management system (Montgomery 1992) is also a subset of the Information Management System currently being developed for the ER Program. Records management functions are initlated whenever a document is created. The records management support functions ensure that documents are stored so that they may be retrieved readily when needed.

\subsubsection{Environmental Restoration Program Configuration Management System}

Releasing ER Program environmental engineering documents through the Configuration-Management operated engineering release work stations provides control and transmittal for these documents into the Hanford Site configuration management system and transmittal of the documents to Central Files for record purposes and distribution. A configuration management plan currently is being developed for the ER Program.

\subsubsection{Environmental Restoration Program Information Matrix}

A list of records and documents (or record/document types) has been extracted from the ER Program requirements and planning documents, the Tri- 
Party Agreement, and the Tri-Party Agreement Handbook, augmented by the records and documents that are generated by WHC working-level procedures, such as those contained in WHC-CM-7-7. RL, ER Program, Tri-Party Agreement, and WHC records management and document control requirements have been incorporated into this list or matrix, which is intended to provide guidance to assist ER Program performing organizations to identify the requirements that apply to specific ER Program information.

This matrix provides an annotated list of ER Program information in tabular form, listing ER Program information in alphabetical order by title and including input from ER Program performing organizations relating to record keepers and responsible organizations, information 1 ife cycle/phases, information categories and classifications, and processing requirements. This matrix will be kept in an electronic database at the EPIC, and the database will be updated as ER Program requirements change.

\subsection{DOCUMENT CONTROL PLAN IMPLEMENTATION}

\subsection{INTRODUCTION}

This chapter describes the roles of ER Program performing organizat uns in the implementation of the ER Document control plan and describes the major activities needed for effective implementation.

\subsection{PERFORMING ORGANIZATION ROLES}

\subsubsection{Environmental Restoration Progran Office}

To effectively implement this plan, the ER Program office must identify any additional program documents that need to be controlled, but that are not currently controlled by the existing document control systems and have not been identified as requiring control by the performing organizations. These documents will be identified to the responsible cost account manager.

\subsubsection{Information Resource Management Department}

The IRM Department is responsible for implementing this plan. To effectively implement this plan, the IRM Department will continue to operate its current document control systems and integrate environmental regulatory requirements into its systems to meet the needs of the ER Program for documents needed to fulfill dual roles (meeting RL and regulatory requirements).

The IRM Department also will provide matrixed personnel as needed for the EPIC to provide required services and, as required by WHC-CM-3-5, review and approve plans and procedures for performing organizations that establish and implement or modify the ER Program document control system. 
Effectively implementing this plan also will require that the IRM Department continue to assist ER Program performing organizations, both document-generating and support organizations, in the development of RIDS for ER Program documents and to ensure timely approval of RIDS submitted to them for review and approval.

\subsubsection{Environmental Records and Information Services}

The Environmental Records and Information Services (ERIS) organization, within the IRM Department, is the primary organization responsible for implementing this plan. ERIS will assist the WHC ER Program Office in implementing this plan and will coordinate with other IRM Department organizations to ensure compliance with the applicable governing requirements pertaining to document control. following.

ERIS also will assist ER Program performing organizations in the

- Identify documents requiring or needing control.

- Identify the method of control to be placed on each document requiring or needing control.

- Develop and document (procedures, plans, etc.) internal systems to control documents that are outside the scope of the existing document control systems.

- Control documents, as requested, that are outside the scope of the existing document control systems.

- Interface with other IRM organizations and Configuration Management.

- Provide training on the EPIC to ensure effective implementation and utilization of the center.

\subsubsection{Configuration Management}

The Configuration Management organization will continue to operate the current engineering document control systems relative to identification, change control, status control, and verification of engineering and environmental engineering documents.

To effectively implement this plan, the Configuration Management organization will provide procedures and personnel to provide release, processing, and control of environmental engineering documentation for the ER Program.

\subsubsection{Performing Organizations}

The heavy burden for effectively implementing this plan is being placed on the organizations that generate the ER documents requiring contro1. These 
WHC-EP-0433

performing organizations include, but are not 1 imited to, WHC, its contractors, and subcontractors supporting ER work activities.

To ensure that this $\mathrm{plan}$ is effectively implemented, each performinc organization within the ER Program will develop and maintain procedures that ensure compliance with the requiroments of this plan. Procedures are discussed in Section 5.3.1 of this plan.

\subsection{IMPLEMENTING ACTIVITIES}

To effectively implement this $\mathrm{plan}$ and to provide for an orderly and efficient flow of information during that process, a three-phase approach has been developed.

The first phase is to establish implementing procedures and related desk instructions, as needed. Procedures are discussed in detail in Section 5.3.1 of this plan.

The second phase will be to train all ER performing organizations. This is discussed in Section 5.3.2 of this plan.

The third phase will be to secure feedback from ER Program performing organizations and to revise the plan, as necessary.

\subsubsection{Procedures}

Document control procedures already used by the performing organizations will be reviewed against the requirements of this $p l$ an and consolidated, integrated, or revised, as necessary. Where no procedures currently exisit, they will be developed. This phase of the implementation process will require coordination between the ERIS organization, other IRM organizations, and the performing organizations.

A network of detailed implementing procedures is necessary to ensure that this plan is consistently implemented. Each performing organization involved in the generation of documents requiring control will be required to document this process in their organization's implementing procedures. The performing organizations also must identify the methods of document control for their documents, and based on the level of control desired, may need to develop their own document control system in cases where existing systems do not meet their needs. Such systems must meet the requirements of this plan and must be reviewed and concurred with by IRM before implementation.

The current Hanford Site document control systems are well established, well documented, and invaluable resources of information pertaining to the methods of control and the documents that require this control. These resources should be used to the greatest extent possible when additional document control systems and procedures are required. 
WHC-EP-0433

The document control systems (including how performing organizations interface with the existing systems) shall be procedurally controlled in the performing organization's procedures, which shall provide the following.

- Identify documents to be controlled and their distribution requirements. Controlled distribution may be accomplished by copy control or general distribution methods depending on the degree of control deemed necessary by ER Program management.

If additional control is necessary (beyond what is identified for the document type in the established document control system) ER Program management will identify (in their procedures) the type of additional control to be placed on the document type. In either case, procedures shall require that all recipients of the initial distribution receive all subsequent revisions, provided that they have not been removed from controlled distribution.

- Identify requirements and the assignment of responsibility for preparing, reviewing, approving, issuing or distributing, and revising documents.

- Review documents for adequacy, completeness, and correctness before approval and issuance.

- Account for those documents controlled by each system and ensure visibility of revision status (revision recorded on document).

Technical working-level procedures prepared by the performing organizations must comply with the requirements of WHC-CM-3-5, Section 12.5, except for procedures controlled by Management Standards or desk instructions.

\subsubsection{Training}

Training is an essential aspect for the implementation of this plan. A program of training will be necessary for all ER performing organizations. Training also should be given to service and support organizations of the ER Program.

The IRM Department, with assistance from other ER Program performing organizations, will be responsible for the ER document control system training. This training will be developed to fulfill each ER Program performing organization's needs and requirements.

The ERIS organization, within the IRM Department, will continue to wor: with the Tri-Party Agreement Data and Information Management organization to implement the recentiy developed formal environmental training program, which includes identification and processing of AR documents.

At this time, details of the training that will be required for implementation of this plan have not been fully identified. That training will become part of a formal, documented training program that is currentiy being developed for records management and document control for the ER Program. That training also will be coordinated with the formal environmental 
WHC-EP-0433

training program established for identification and processing of $A R$ documents. As they are developed and implemented, details about available and planned training will be incorporated into subsequent revisions to this plan.

\subsection{ANNUAL REVIEW}

Once a system is implemented, the system must undergo periodic audits or self-assessments to determine how effectively it is meeting the requirements and the needs of its customers.

As part of its internal self-assessment program, the ERIS organization will prepare revisions for this plan, as needed. The plan will be reviewed annually for accuracy and relevance to the ER Program. As the implementing process continues and lessons are learned, information will be added and/or updated in this plan, so that it will continue to be an accurate and reliable source of information for managing the ER Program document control system. other performing or affected organizations will continue to be involved in the review, comment, and concurrence process for revisions to this plan.

\subsection{REFERENCES}

Comprehensive Environmental Response, Compensation and Liability Act of 1980, 42 U.S.C 9601 et seq.

DOE-RL, 1990a, Administrative Record Index, RL-TPA-90-0002, U.S. Department of Energy, Richland Fleld Office, Richland, Washington.

DOE-RL, 1990b, Hanford Federal Facility Agreement and Consent Order (Tri-Party Agreement) Handbook, RL-TPA-90-0001, U.S. Department of Energy, Richland Field Office, Richland, Washington.

DOE-RL, 1990c, Public Information Repository (PIR) Handbook, RL-TPA-90-0003, U.S. Department of Energy, Richland Field Office, Richland, Washington.

DOE-RL, 1992a, Environmental Restoration Progran Quality Assurance System Requirements for the Hanford Site, DOE/RL-90-28, Rev. 1, U.S. Department of Energy, Richland Operations Office, Richland, Washington.

DOE-RL, 1992b, Project Management System, RLIP 4700.1A Chg 1, U.S. Department of Energy, Richl and Operations Office, Richland, Washington.

Ecology, EPA, and DOE, 1990, Community Relations Plan for the Hanford Federal Facility Agreement and Consent Order, Benton County, Washington, Washington State Department of Ecology, U.S. Environmental Protection Agency, and U.S. Department of Energy, Olympia, Washington.

Ecology, EPA, and DOE, 1992, Hanford Federal Facility Agreement and Consent Order, Vols. I and 2, as amended, Washington State Department of Ecology, U.S. Environmental Protection Agency, and U.S. Department of Energy, olympia, Washington. 
Montgomery, L., 1992, Environmental Restoration Program Records Management Plan, WHC-EP-0430, Rev. 1, Westinghouse Hanford Company, Richland, Washington.

Resource Conservation and Recovery Act of 1976, 42 U.S.C 6901 et seq.

WHC-CM-1-1, Management Polictes, Westinghouse Hanford Company, Richland, Washington.

WHC-CM-1-3, Management Requirements and Procedures, Westinghouse Hanford Company, Richland, Washington.

WHC-CM-3-4, Information Release Administration, Westinghouse Hanford Company, Richland, Washington.

WHC-CM-3-5, Document Control and Records Management Manual, Westinghouse Hanford Company, Richland, Washington.

WHC-CM-3-6, Uniform Publication System, Westinghouse Hanford Company, Richland, Washington.

WHC-CM-4-2, Quality Assurance Manual, Westinghouse Hanford Company, Richland, Washington.

WHC-CM-6-1, Standard Engineering Practices, Westinghouse Hanford Company, Richland, Washington.

WHC-CM-7-7, Environmental Investigations and Site Characterization Manual, Westinghouse Hanford, Richland, Washington.

WHC-CM-8-8, Job Control Systen, Westinghouse Hanford Company, Richland, Washington.

\subsection{GLOSSARY}

\section{ACRONYMS AND ABBREVIATIONS}

$\begin{array}{ll}\text { AR } & \text { Administrative Record } \\ \text { CERCLA } & \text { Comprehensive Environmental Response, Compensation and } \\ \text { CRP } & \text { Liability Act of } 1980 \\ & \text { Community Relations Plan for the Hanford Federal Facility } \\ \text { DOE } & \text { Agreement and Consent Order } \\ \text { ECOlogy } & \text { Washingartment of Energy } \\ \text { EDMC } & \text { Environmental Data Management Center } \\ \text { EPA } & \text { U.S. Environmental Protection Agency } \\ \text { EPIC } & \text { Environmental Restoration Program Information Center } \\ \text { ER } & \text { Environmental Restoration } \\ \text { ERIS } & \text { Environmental Records and Information Services } \\ \text { IRM } & \text { Information Resource Management }\end{array}$


WHC-EP-0433

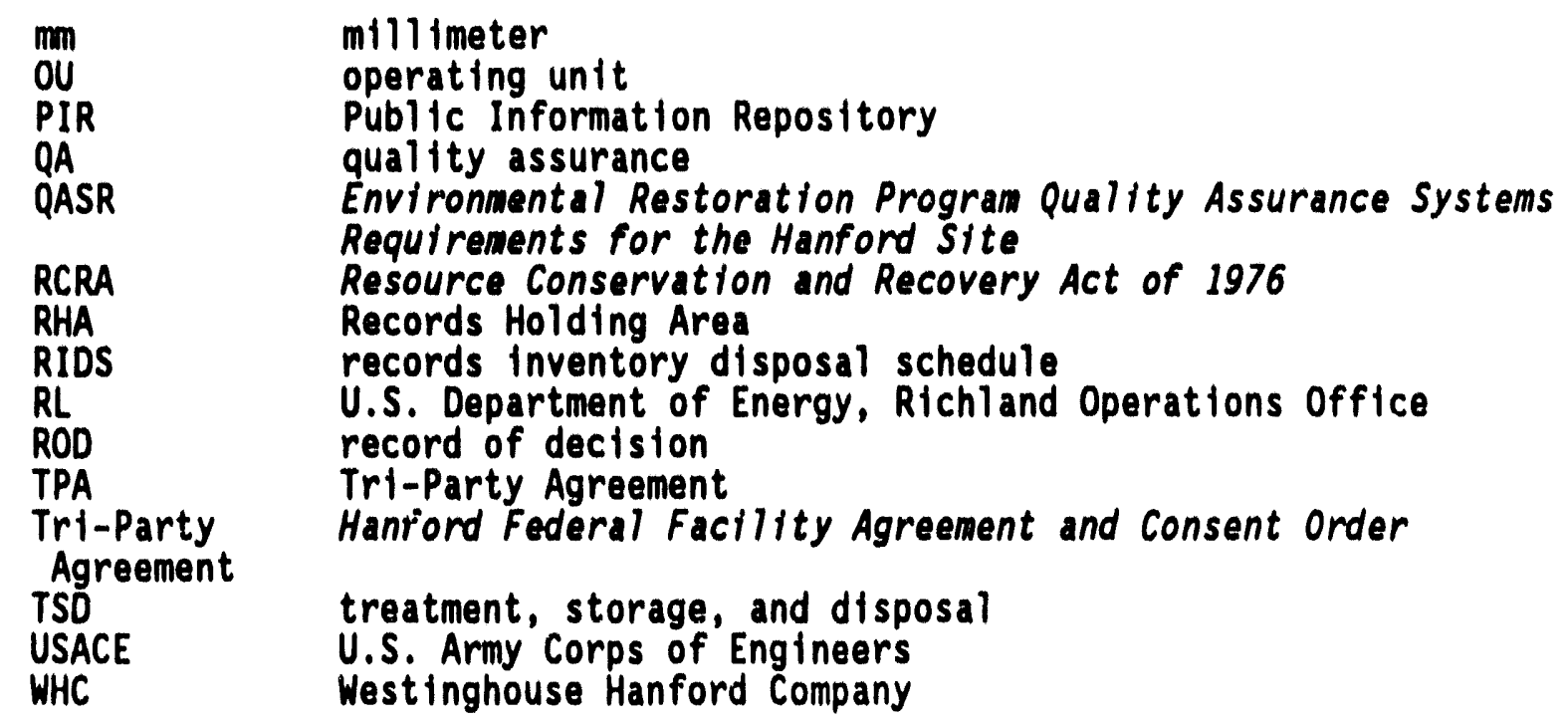

\section{TERMS AND DEFINITIONS}

Administrative Record (AR). The Comprehensive Environmental Response, Compensation and Liabllity Act of 1980 (CERCLA) identifies the AR as the official file that contains all information that was considered or relfed upon by the regulatory agency in arriving at a final remedial action decision, as well as all documentation of public participation throughout the process. The Resource Conservation and Recovery Act of 1976 (RCRA) Identifies the AR as the official flle that contains all documents to support a final RCRA permit determination.

Administrative Record File. The assemblage of documents compiled and maintained by an agency pertaining to a proposed project or administrative action and designated as AR or that are candidates for inclusion in the $A R$ once a record of decision is attained.

Administrative Record Elle Index. A detalled 1 isting of all documents in an AR file.

Change Control. A Configuration Management process that ensures that all changes are properly identifled, designed, approved, implemented, and documented.

Controlled Distribution. The transmittal of controlled documents and all subsequent revisions to specific individuals or locations.

Controlled Document. Any document requiring formal controls for preparation, accountability, review and approval, revision, access, or distribution.

Controlled Notebook. A controlled, bound or unbound, notebook used for recording scientific and/or technical information.

Cooy Control Distribution. A type of controlled distribution that identifies each specific copy of a document with a unique number and assigns 
Individual copy holders to facllitate recelpt accountabllity for documents and revisions, recall of documents, and removal of obsolete or superseded documents from the work areas and restrict access when desired.

Direct Revision. A change made to the body of a document that revises, adds, or deletes information. The revised document supersedes the prevtous document reviston.

Decument. Any written or graphic information describing, defining, spectfying, reporting, or certifying activities, requirements, procedures, or results.

Document Control. The act of ensuring that documents, and changes thereto, are reviewed for adequacy, completeness, and correctness, approved for release or use by authorized personnel, and distributed to and used at the location where the prescribed activity is performed.

Engineering Decuments. Technical documents (not including procedures) prepared to support the planning, analysis, design, construction, operation, and maintenance of a specific design for structure, system, or component.

Environmental Data Management Center (EDMC). The central fac 11 ity and services that provide a flles management system for processing Environmental Restoration (ER) Program AR/PIR information.

Environmental Engineering Documentation. Environmental engineering documents (specifically DOE/RL-NN-NN numbered federal agency technical publications) include environmental work plans, feasibility studies, aggregate area management studies, and remedial investigation reports released in draft and/or final form.

Environmental Restoration Proaram Information Center (EPIC). The central facility and services, including satellite facilities, that provide processing and retrieval of ER Program information (data, documents, and records) utflizing existing company systems to control documents and manage records.

ER Project File. The body of records applicable to a waste site necessary to demonstrate regulatory compliance, to show compliance with governing requirements (regulatory and DOE), and to provide a traceable project history. It is a gathering of information that substantiates, supports, or documents a specific scope of work identified in the ER Program work breakdown structure.

General Distribution. A type of controlled distribution that distributes coples of a controlled document to spectfic individuals or locations identified on a distribution list.

Page Change. A variation of the direct revision that changes information only on affected pages instead of revising the entire document.

Procedure. A step-by-step sequence for performing an activity or process. There are three kinds: administrative, emiargency, and technical. 
Proaram Participant. An organization or individual directed by RL to perform ER Program work. (Currently Westinghouse Hanford and the U.S. Army Corps of Engineers.)

Performing Organization. An organization within WHC or contracted to WHC that is responsible for performing activitles in support of the ER Program.

Primary Document. A document that contains information on which key decistons are made with respect to the remedial action or permitting process. Primary documents are subject to dispute resolution and are part of the AR file.

Record Copy. The designated "offictal" copy.

Secondary Document. A document providing information that does not, in itself, reflect or support key decistons. A secondary document is subject to review by the regulatory agencles and may be part of the administrative record file. It is not subject to dispute resolution.

Uncontrolled Distribution. A type of document distribution that distributes coptes of controlled documents to individuals or locations upon request, with no restrictions on access and no record of the reciplents. 
WHC-EP-0433

This page intentionally left blank. 
WHC-EP-0433

\section{APPENDIX A}

\section{ENVIRONMENTAL RESTORATION (ER) PROGRAM DOCUMENT LIST}


WHC-EP-0433

This page intentionally left blank. 


\section{APPENDIX $A$}

\section{ENVIRONMENTAL RESTORATION PROGRAN DOCUMENT LIST}

This list of typical ER Program documents or document types has been compiled for use by ER Program performing organizations to assist them in categorizing and controlling their specific ER Program documents.

This list identifies the document control systems through which many existing ER Program documents have been processed and is designed to provide guidance to determine how to issue specific program documents. The list is not intended to be all inclusive, and it will be updated in subsequent revisions to this plan.

Appendix A. Environmental Restoration (ER) Program Documents.

\begin{tabular}{|c|c|c|c|c|c|}
\hline 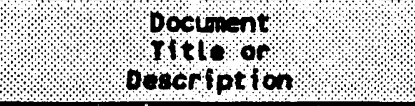 & $\begin{array}{l}\text { source } \\
\text { boutrount }\end{array}$ & $\begin{array}{l}\text { oocumont } \\
\text { corpegor }\end{array}$ & $\begin{array}{l}\text { orfoinating/ } \\
\text { Respongible: } \\
\text { organization }\end{array}$ & $\begin{array}{l}\text { Interin } \\
\text { Record Keeping } \\
\text { organization }\end{array}$ & $\begin{array}{l}\text { Record } \\
\text { Copy } \\
\text { Holder }\end{array}$ \\
\hline Adininiletratt we Record $(A R)$ & $\begin{array}{l}\text { Tri-Party Agreenent } \\
\text { RL-TPA-90-0001 }\end{array}$ & FMP & ERIS & ERIS & CF \\
\hline $\begin{array}{l}\text { Amulat surveill lance and } \\
\text { Wintenance Reports for } \\
\text { the Retifed Hanford sito } \\
\text { Focillities }\end{array}$ & TBD & EP & DS/IFSEH & ERO & CF \\
\hline Cherectorlization oocuents & mac & $\begin{array}{l}\text { Environ. } \\
\text { Eng. Doc. }\end{array}$ & ERO & ERO & DS \\
\hline Cleen Uoter Permits. & $\begin{array}{c}\text { MAC } \\
\text { CMA/33CFR } 330 \\
\text { WHC-CH-7-5 }\end{array}$ & TED & ARUP & A\&UP & CF \\
\hline closure plons & $\begin{array}{c}\text { RCRA } \\
\text { MAC } 303-610 \text { (3) (a) } \\
\text { MHC-CN-7-5 }\end{array}$ & FATP & $\begin{array}{l}\text { RCRA } \\
\text { Closures }\end{array}$ & $\begin{array}{c}\text { RCRA } \\
\text { Closures }\end{array}$ & CF \\
\hline $\begin{array}{l}\text { Cownity Reletione elen } \\
\text { for the Henford federal } \\
\text { fecilf ity Agree } \\
\text { conent ond }\end{array}$ & $\begin{array}{l}\text { 40CFR } 300.430 \text { (c) } \\
\text { Tri-Party Agreement }\end{array}$ & FMAP & $\begin{array}{l}\text { Public } \\
\text { Involvement }\end{array}$ & com & $\operatorname{com}$ \\
\hline 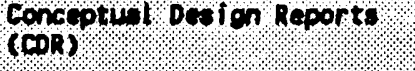 & RLIP 4700.1A & SD & DE & DE & DS \\
\hline $\begin{array}{l}\text { Conf louret on venogenens } \\
\text { Plen (Cup) }\end{array}$ & DOE 4700.1 & FATP & $\begin{array}{l}\text { Central } \\
\text { Engineering }\end{array}$ & PMS & CF \\
\hline Corroct lve neosures oestor & $\begin{array}{c}\text { RCRA/ } \\
\text { WHC-CN-7-7/EII } 1.9 \\
\end{array}$ & FATP & ERE & ERE & CF \\
\hline correstive Measurch & $\begin{array}{c}\text { RCRA/ } \\
\text { WHC-CN-7-7/EII } 1.9\end{array}$ & FATP & ERE & ERE & CF \\
\hline 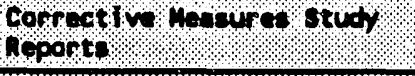 & $\begin{array}{l}\text { RCRA/ } \\
\text { MHC-CH-7-7/EII } 1.9\end{array}$ & FATP & ERE & ERE & CF \\
\hline 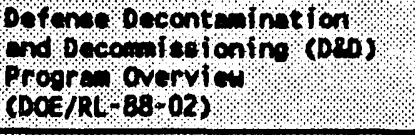 & TEO & FATP & ERO & ERO & DS \\
\hline opcription of wors $(00 y)$ & $\begin{array}{l}\text { WHC-CH-6-1 } \\
\text { WHC-CH-7-7I } \\
\text { EII } 1.14\end{array}$ & $\mathbf{S 0}$ & ERE & $N / A$ & CF \\
\hline Dociont control plans & DOE/RL-89-29 & EP & ERIS & ERIS & CF \\
\hline
\end{tabular}


Appendix A. Environmental Restoration (ER) Program Documents.

\begin{tabular}{|c|c|c|c|c|c|}
\hline $\begin{array}{l}\text { dop } \\
\text { terelort or }\end{array}$ & $\begin{array}{l}\text { opources } \\
\text { kequfremert }\end{array}$ & $\begin{array}{l}\text { ooct went } \\
\text { Typs or } \\
\text { cotegary }\end{array}$ & $\begin{array}{l}\text { orfolnotino/ } \\
\text { Responstble } \\
\text { organization }\end{array}$ & $\begin{array}{l}\text { tuteriw } \\
\text { Record Keeping } \\
\text { organization }\end{array}$ & $\begin{array}{l}\text { Record } \\
\text { Copy } \\
\text { Holder }\end{array}$ \\
\hline snolnerthostudf & WHC-CN-6-1 & So & Cog Eng & $\begin{array}{l}\text { Confio. } \\
\text { Mgint. }\end{array}$ & CF \\
\hline 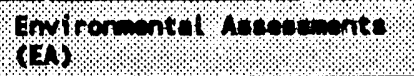 & $\begin{array}{c}\text { MEPA } \\
\text { WHC-CH-7-5/4.0 }\end{array}$ & FATP & $\begin{array}{l}\text { NEPA } \\
\text { Function }\end{array}$ & $\begin{array}{l}\text { NEPA } \\
\text { Function }\end{array}$ & RHA \\
\hline 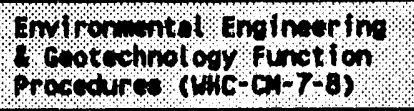 & $\begin{array}{c}D O E / R L-90-28 \\
\text { ReV. } 1\end{array}$ & CN & ERE/EFS/GEO & GEO & CF. \\
\hline 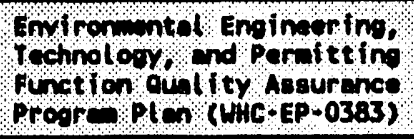 & $\begin{array}{c}\text { DoE/RL- } 90-28, \\
\text { ReV. } 1\end{array}$ & EP & ERE & ERE & $\mathbf{C F}$ \\
\hline 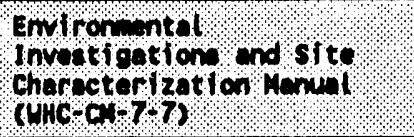 & $\begin{array}{c}\text { DOE/RL-90-28, } \\
\text { ReV. } 1\end{array}$ & an & $\begin{array}{l}\text { Environ. } \\
\text { Division }\end{array}$ & $\begin{array}{l}\text { Document } \\
\text { Control }\end{array}$ & CF \\
\hline 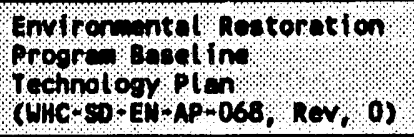 & WHC-EP-0456 & $\infty$ & EPB & PMS & CF \\
\hline 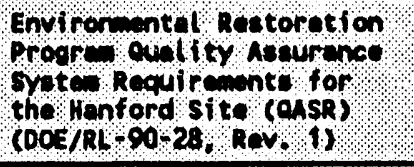 & $\begin{array}{c}\text { DOE } 5700.6 C \\
E M-Q A R 0\end{array}$ & FATP & PSeD & PSeD & CF \\
\hline 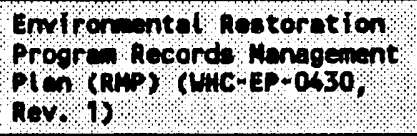 & DOE/RL-89-29 & EP & ERIS & ERIS & CF \\
\hline 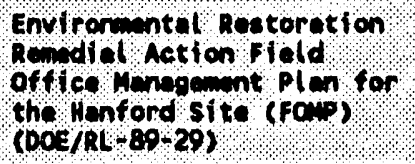 & $\begin{array}{l}\text { ER/ORP-100 } \\
\text { DOE } 4700.1\end{array}$ & FATP & PMS & PMS & CF \\
\hline $\begin{array}{l}\text { Exped ted Response } A c t i o n \\
\text { (ERA) Project Plen }\end{array}$ & TEO & FATP & TBO & TBD & TBD \\
\hline 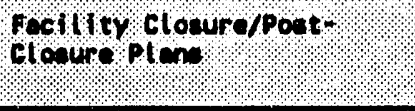 & $\begin{array}{c}\text { RCRA } \\
\text { wAC } 303-610 \text { (3) (a) } \\
\text { WHC-CH-7-5 }\end{array}$ & FATP & $\begin{array}{l}\text { RCRA } \\
\text { Closures }\end{array}$ & $\begin{array}{l}\text { RCRA } \\
\text { Closures }\end{array}$ & CF \\
\hline 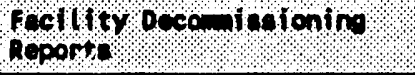 & DOE 5480.2A & EP/IP & DE & DE & DS \\
\hline 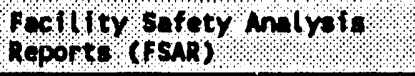 & WHC-CN-4-46 & So & SARR & $\begin{array}{l}\text { Config. } \\
\text { Mgmt. }\end{array}$ & CF \\
\hline 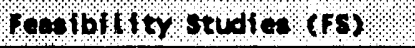 & WHC-CN-7-7/EII 1.9 & FATP & ERE & ERE & CF \\
\hline 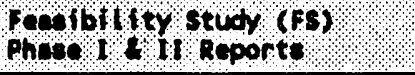 & CERCLA & FATP & ERE & ERE & CF \\
\hline 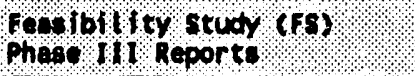 & CERCLA & FATP & ERE & ERE & CF \\
\hline Std $100,00 k$ & МHC-CH-7-7/EII 1.5 & $\begin{array}{l}\text { Control led } \\
\text { Documents }\end{array}$ & $\begin{array}{l}\text { ERE/ } \\
\text { EFS/GEO } \\
\text { Assignoe }\end{array}$ & $\begin{array}{l}\text { ERE/ } \\
\text { EFS/GEO } \\
\text { Assignee }\end{array}$ & RHA \\
\hline 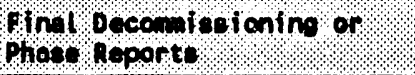 & WHC-CH-1-6 & TED & DE & DE & DE \\
\hline 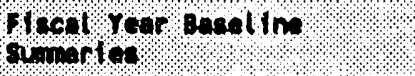 & TED & FATP & EPB & PMS & PMS \\
\hline
\end{tabular}


Appendix A. Environmental Restoration (ER) Program Documents.

\begin{tabular}{|c|c|c|c|c|c|}
\hline $\begin{array}{l}\text { oocumin } \\
\text { ofitle or } \\
\text { oceription }\end{array}$ & $\begin{array}{l}\text { sourcen } \\
\text { Roquir mecunt }\end{array}$ & $\begin{array}{l}\text { Document } \\
\text { Type or } \\
\text { catecory }\end{array}$ & $\begin{array}{l}\text { Originating/ } \\
\text { Responsible } \\
\text { Organization }\end{array}$ & $\begin{array}{l}\text { Interim } \\
\text { Record Keeping } \\
\text { Orgenization }\end{array}$ & $\begin{array}{l}\text { Record } \\
\text { Copy } \\
\text { Holder }\end{array}$ \\
\hline $\begin{array}{l}\text { flecal Year (FY) } \\
\text { progre } \text { Project work plans }\end{array}$ & TBO & FATP & EPB & EPB & CF \\
\hline Functionst beston criterle & RLIP $4700.1 A$ & SD & DE & DE & DS \\
\hline 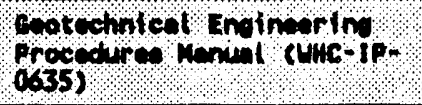 & $\begin{array}{c}\text { DOE/RL-90-28, } \\
\text { ROV. } 1\end{array}$ & IP & GEL & GEL & CF \\
\hline 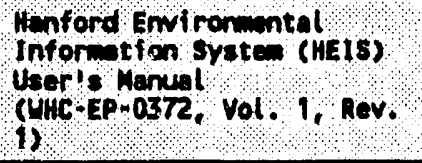 & WHC-CA-3-10 & EP & EDN & EDM & CF \\
\hline 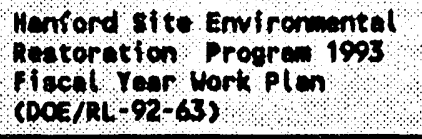 & $\begin{array}{l}\text { Henford site } \\
\text { Menegement system }\end{array}$ & FATP & EPC & PMS & CF \\
\hline 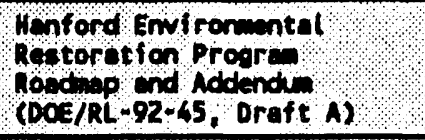 & $\begin{array}{l}\text { DOE - Ha Rosdmap } \\
\text { Methodol oor } \\
\text { Document }\end{array}$ & FATP & EPB & EPB & CF \\
\hline 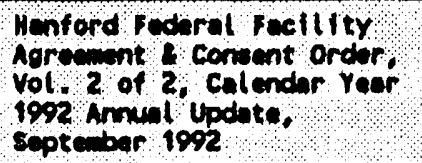 & $\begin{array}{l}\text { CERCLA/RCRA/ } \\
\text { Execut ive Order } \\
12580\end{array}$ & FATP & TPA & TPA & TPA \\
\hline 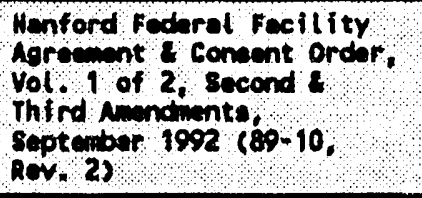 & $\begin{array}{l}\text { CERCLA/RCRA/ } \\
\text { Execut ive Order } \\
12580\end{array}$ & FATP & TPA & TPA & TPA \\
\hline $\begin{array}{l}\text { Henford Fedirel Fecillty } \\
\text { Agreant and Coneent } \\
\text { Ordar (TrI-Perty } \\
\text { Agreement) Handbook } \\
\text { (RL-TPA-90-0001) }\end{array}$ & $\begin{array}{l}\text { RL Letter } \\
91-\text { TPA-123 }\end{array}$ & FMAP & TPA & ERIS & CF \\
\hline 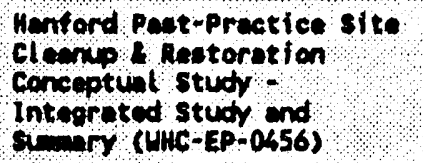 & Teo & EP & ERE & ERE & CF \\
\hline $\begin{array}{l}\text { Hanford Renedial Action } \\
\text { Environental Impact } \\
\text { settenent nenapement } \\
\text { Action Plans }\end{array}$ & MEPA & FATP & PMS & PMS & PMS \\
\hline 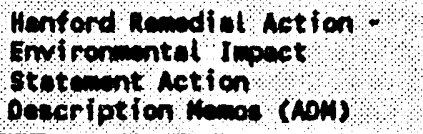 & MEPA & FATP & PWS & PMS & PMS \\
\hline 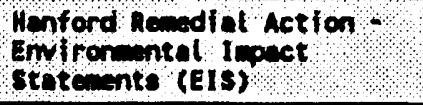 & NEPA & FATP & $\begin{array}{l}\text { MEPA } \\
\text { Function }\end{array}$ & $\begin{array}{l}\text { NEPA } \\
\text { function }\end{array}$ & RHA \\
\hline 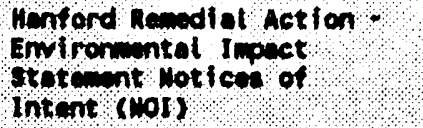 & MEPA & FATP & PMS & PMS & PMS \\
\hline
\end{tabular}


Appendix A. Environmental Restoration (ER) Program Documents.

\begin{tabular}{|c|c|c|c|c|c|}
\hline $\begin{array}{l}\text { oocunint } \\
\text { fittle or } \\
\text { Description }\end{array}$ & $\begin{array}{l}\text { source } \\
\text { Requifrement } \\
\text { Document }\end{array}$ & $\begin{array}{l}\text { oocument } \\
\text { Type or } \\
\text { Category }\end{array}$ & $\begin{array}{l}\text { Originating/ } \\
\text { Responsible } \\
\text { Organization }\end{array}$ & $\begin{array}{l}\text { Interim } \\
\text { Record Keeping } \\
\text { Organization }\end{array}$ & $\begin{array}{l}\text { Record } \\
\text { Copy } \\
\text { Holder }\end{array}$ \\
\hline 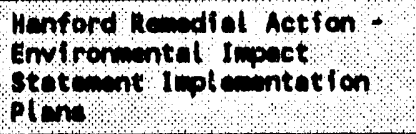 & MEPA & FATP & PMS & PMS & PMS \\
\hline 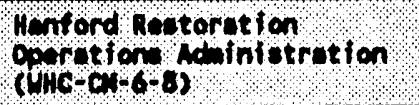 & DOE $5820.2 A$ & Cn & ERO & ERO & CF \\
\hline 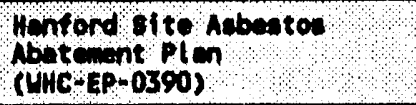 & WHC-CN-7-5/3.0 & EP & DS & ERO & CF \\
\hline 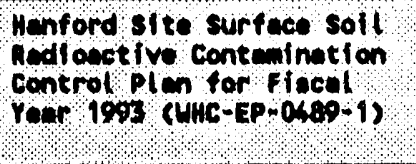 & $\begin{array}{l}\text { U.S. DoE Policy } \\
\text { for Acceptance } \\
\text { of Fecilitios } \\
\text { for Emironmentel } \\
\text { Restoration }\end{array}$ & EP & DE & ERO & CF \\
\hline $\begin{array}{l}\text { Hentord site wante } \\
\text { (Honsugent) }\end{array}$ & HSwa $3004(u)$ & FATP & EDM & EDM & CF \\
\hline 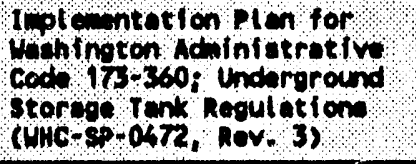 & TED & $\mathbf{s p}$ & DE & ERO & CF \\
\hline $\begin{array}{l}\text { Ioploment ing Instructions } \\
\text { or oek Instruction }\end{array}$ & $\begin{array}{c}\text { DOE/RL- } 90-28 \\
\text { ReV. I }\end{array}$ & IP & ERIS & ERIS & CF \\
\hline $\begin{array}{l}\text { Information Menogenent } \\
\text { Svite Plene }\end{array}$ & DOE/RL-89-29 & FATP & PMS & PMS & CF \\
\hline Inter in neseure Proposels & $\begin{array}{c}\text { RCRA } \\
\text { UHC-CN-7-7/EII } 1.9\end{array}$ & FATP & ERE & ERE & CF \\
\hline $\begin{array}{l}\text { Interlin Response Action } \\
\text { (IRA) Proposal: }\end{array}$ & $\begin{array}{c}\text { CERCLA } \\
\text { WHC-CH-7-7/EII } 1.9\end{array}$ & FATP & ERE & ERE & CF \\
\hline $\begin{array}{l}\text { Interlo stabilizention } \\
\text { Plens }\end{array}$ & WHC-EP-0489-1 & IP & DE & DE & DS \\
\hline Menagoentent Action Plens & HHC-CH-7-5/10 & IP & REGSUP & REGSUP & CF \\
\hline $\begin{array}{l}\text { Wulet ryear progren } \\
\text { Plmp/Protect plens: }\end{array}$ & TBO & FATP & EPB & EPB & CF \\
\hline Notfer of Intent (NOI) & WHC-CN-7-5 & $T B D$ & $\begin{array}{l}\text { REGSUP/ } \\
\text { RCRA } \\
\text { Permita }\end{array}$ & $\begin{array}{l}\text { RCRA } \\
\text { Permits }\end{array}$ & CF \\
\hline Pert A Promit Appl fent fon & $\begin{array}{l}\text { RCRA } \\
\text { MAC } 173-303 \text { I } \\
\text { WHC-CN-7-5 }\end{array}$ & FATP & $\begin{array}{l}\text { RCRA Unit } \\
\text { Permits }\end{array}$ & $\begin{array}{l}\text { RCRa Unit } \\
\text { Permits }\end{array}$ & EF \\
\hline Port ef notices of & $\begin{array}{c}\text { RCRA } \\
\text { WMC } \\
\text { WHC-CN-7-5 }\end{array}$ & FATP & $\begin{array}{l}\text { RCRA Unit } \\
\text { Permits }\end{array}$ & $\begin{array}{l}\text { RCRA Unit } \\
\text { Permits }\end{array}$ & CF \\
\hline port p pornit Appllications & $\begin{array}{l}\text { RCRA } \\
\text { WAC 173-303/ } \\
\text { WHC-CH-7-5 }\end{array}$ & FATP & $\begin{array}{l}\text { RCRA Unit } \\
\text { Permits }\end{array}$ & REGSUP & CF \\
\hline 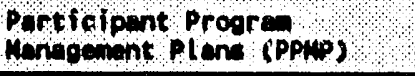 & TBO & EP & EPB & EPB & CF \\
\hline permiteting plens & WHC-CH-7-5 & TBO & REGSUP & REGSUP & CF \\
\hline Bont-cloure plene & WAC $\begin{array}{c}173-303-160 \text { (6) } \\
\text { WHC-CH-7-5 }\end{array}$ & FATP & Cl scra & RCRA Closure & CF \\
\hline
\end{tabular}


Appendix A. Environmental Restoration (ER) Program Documents.

\begin{tabular}{|c|c|c|c|c|c|}
\hline $\begin{array}{l}\text { oosmint } \\
\text { tftlo or } \\
\text { Doweription }\end{array}$ & $\begin{array}{l}\text { sourat } \\
\text { Requirimant } \\
\text { Dowimint }\end{array}$ & $\begin{array}{l}\text { Dotumint } \\
\text { Type or } \\
\text { Catogom }\end{array}$ & $\begin{array}{l}\text { Originating/ } \\
\text { Respons ible } \\
\text { Organization }\end{array}$ & $\begin{array}{l}\text { Interim } \\
\text { Record Keeping } \\
\text { organization }\end{array}$ & $\begin{array}{l}\text { Record } \\
\text { Copy } \\
\text { Holder }\end{array}$ \\
\hline Preduct fond Documents & WHC-CN-3-6 & FATP & Originator & Originator & CF \\
\hline Project Handgenent Plans & RLIP $4700.1 \mathrm{~A}$ & so & GEO & GEO & CF \\
\hline Project Plens & DOE 4700.1 & FATP & EPB & PMS & CF \\
\hline 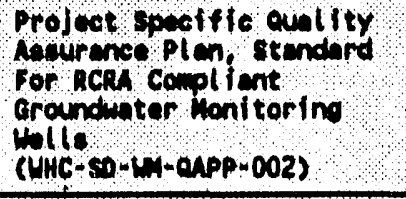 & TEO & $\infty$ & EQA & EQA & $\mathbf{C F}$ \\
\hline $\begin{array}{l}\text { Publ fo Informat ion } \\
\text { Repos I tory Handbook } \\
\text { (RL-TPA- } 90-0003)\end{array}$ & Bup & FAP & ERIS & ERIS & $\mathbf{C F}$ \\
\hline 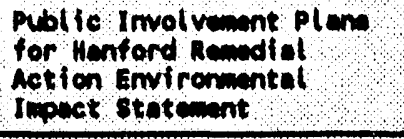 & NEPA & FMAP & $\begin{array}{l}\text { Public } \\
\text { Imvolvement }\end{array}$ & con & COM \\
\hline 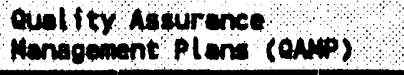 & $\begin{array}{c}\text { DOE/RL- } 90-28, \\
\text { ReV. } 1\end{array}$ & $\mathbf{S O}$ & PSED & PSED & CF \\
\hline $\begin{array}{l}\text { Quil I ty hourence project } \\
\text { Plens (QAPIP) }\end{array}$ & $\begin{array}{c}\text { DOE/RL- } 90-28 \text {, } \\
\text { ReV. } 1\end{array}$ & $\mathbf{s 0}$ & EQA & EQA & CF \\
\hline 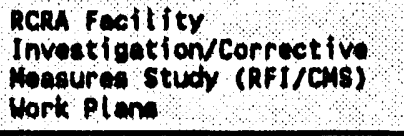 & $\begin{array}{c}\text { RCRA } \\
\text { WHC-CH-7-7/EII } 1.9\end{array}$ & SD & ERE & ERE & CF \\
\hline Records of Deciston (ROD) & $\begin{array}{l}\text { CERCLA } \\
\text { Trf-Party Agreenent }\end{array}$ & TBD & $\begin{array}{l}\text { EPA/ } \\
\text { Ecology }\end{array}$ & EPA & EPA \\
\hline Record Control Procedures & WHC-CN-3-5 & IP & DS & DS & $\mathbf{C F}$ \\
\hline Plend & $\begin{array}{c}\text { CERCLA } \\
\text { WHC-CH-7-7/EII } 1.9\end{array}$ & $\mathbf{s}$ & ERE & ERE & CF \\
\hline $\begin{array}{l}\text { Renedial Action oesion } \\
\text { (RA) Reports }\end{array}$ & $\begin{array}{c}\text { CERCLA } \\
\text { WHC-CN-7-7/EII } 1.9\end{array}$ & $\mathbf{S O}$ & ERE & ERE & CF \\
\hline $\begin{array}{l}\text { Renedicl Imvertiontion } \\
\text { (RI) Phase } 1 \text { Reports }\end{array}$ & $\begin{array}{c}\text { CERCLA } \\
\text { WHC-CH-7-7/EII } 1.9\end{array}$ & $\mathbf{s o}$ & ERE & ERE & CF \\
\hline 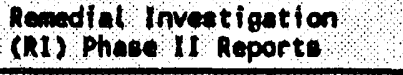 & $\begin{array}{c}\text { CERCLA } \\
\text { WHC-CH-7-7/EI1 } 1.9\end{array}$ & $S$ & ERE & ERE & CF \\
\hline 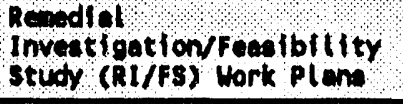 & $\begin{array}{c}\text { CERCLA } \\
\text { WHC-CN-7-7/E II } 1.9\end{array}$ & FATP & ERE & ERE & CF \\
\hline oendigtton ard & TED & $\mathbf{S D}$ & EFS & EFS & CF \\
\hline enfety Anllyes & WHC-CN-6-46 & $\mathbf{s o}$ & SNeR & $\begin{array}{l}\text { Config. } \\
\text { Ment. }\end{array}$ & CF \\
\hline Sofety end we lth ptens & TED & TEO & PSeD & PSeD & PS\&D \\
\hline 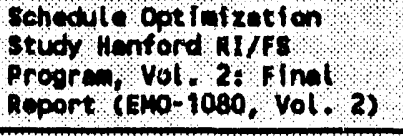 & $\begin{array}{l}\text { Auoust 29, } 1991 \\
\text { Dispute Resolution } \\
\text { Comittes Decision } \\
\text { Statement }\end{array}$ & TeO & Eno & ERP & EMO \\
\hline 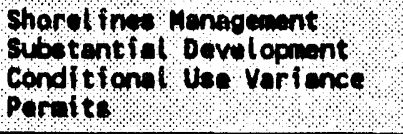 & WHC-CM-7-5 & TEO & ARWP & ARLP & CF \\
\hline
\end{tabular}


Appendix A. Environmental Restoration (ER) Program Documents.

\begin{tabular}{|c|c|c|c|c|c|}
\hline $\begin{array}{l}\text { Dociment } \\
\text { ritele or } \\
\text { Deseription }\end{array}$ & $\begin{array}{l}\text { Source } \\
\text { Requircmant } \\
\text { Documant }\end{array}$ & $\begin{array}{l}\text { Documint } \\
\text { Type or } \\
\text { Category }\end{array}$ & $\begin{array}{l}\text { Originatino/ } \\
\text { Responsible } \\
\text { Organization }\end{array}$ & $\begin{array}{l}\text { Interim } \\
\text { Record Keeping } \\
\text { Organization }\end{array}$ & $\begin{array}{l}\text { Record } \\
\text { Copy } \\
\text { Holder }\end{array}$ \\
\hline $\begin{array}{l}\text { Sof tware conffouration } \\
\text { Managoment Plans }\end{array}$ & MHC-CN-3-10 & so & ERIS & ERIS & CF \\
\hline $\begin{array}{l}\text { Softwipe owion } \\
\text { Decerfiptions }\end{array}$ & WHC-CN-3-10 & 80 & ERIs & ERIS & CF \\
\hline $\begin{array}{l}\text { Sof tware Project } \\
\text { Menugement Plens. }\end{array}$ & NHC-CN-3-10 & $\mathbf{s 0}$ & ERIS & ERIS & CF \\
\hline $\begin{array}{l}\text { sofeware Requil ramente } \\
\text { speciffection }\end{array}$ & MHC-CH-3-10 & $\infty$ & ERIS & ERI8 & CF \\
\hline $\begin{array}{l}\text { Software Verification and } \\
\text { Validation plans }\end{array}$ & WHC-CH-3-10 & so & ERIS & ERIS & CF \\
\hline specification & WHC-CH-6-1/EP-1.2 & Specs. & Originator & $\begin{array}{l}\text { Config. } \\
\text { Mgmt. }\end{array}$ & CF \\
\hline 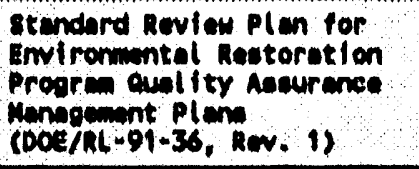 & $\begin{array}{l}\text { DOE/RL- } 90-28 \\
\text { REV. } 1\end{array}$ & FATP & PS\&D & PSED & CF \\
\hline 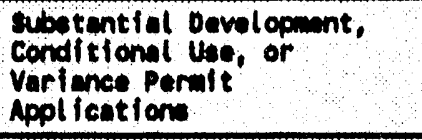 & WHC-CN-7-5 & TOO & ACAP & ALAP & CF \\
\hline $\begin{array}{l}\text { gurplue fecllitien Progra } \\
\text { Plens }\end{array}$ & $\begin{array}{l}\text { Decommisstoning } \\
\text { RCRA Closure } \\
\text { Progrem }\end{array}$ & EP & DE & ERO & CF \\
\hline $\begin{array}{l}\text { survolll ance and } \\
\text { Mointenence Plans }\end{array}$ & WHC-CH-1-6 & IP & DS & DS & DS \\
\hline subproject Besel ine Books & TBO & TED & EPB & PMS & PMS \\
\hline $\begin{array}{l}\text { Syutem Englneering } \\
\text { Munogument plen (SEaw) }\end{array}$ & DOE 4700.1 & FATP & EES & PMS & CF \\
\hline $\begin{array}{l}\text { Toat Plons, Procectures or } \\
\text { specification }\end{array}$ & HHC-CN-6-1/APP. $K$ & $\mathbf{s}$ & Originator & Conf. Mgt. & CF \\
\hline $\begin{array}{l}\text { The future For Nenford: } \\
\text { Ueend and Clemp (sumery } \\
\text { of the Find Report of the } \\
\text { Henford future site Uaes } \\
\text { Working Group) }\end{array}$ & MEPA & GIP & $\begin{array}{l}\text { Spacial } \\
\text { Projects }\end{array}$ & PMS & CF \\
\hline 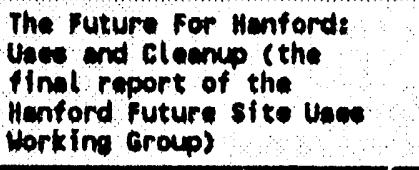 & MEPA & GIP & $\begin{array}{l}\text { Speciol } \\
\text { Projecte }\end{array}$ & PMS & CF \\
\hline $\begin{array}{l}\text { Trostabillity Imvestiontion } \\
\text { Work Plens }\end{array}$ & TED & TED & TBO & TBD & TBD \\
\hline $\begin{array}{l}\text { Treatublility Study Work } \\
\text { plent I Cherecterization } \\
\text { Plone }\end{array}$ & TEO & TED & TBO & TBD & $T B D$ \\
\hline $\begin{array}{l}\text { Tri-party Agrwemont } \\
\text { Complity nolationa Plen } \\
\text { for the Hanford site } \\
\text { Benton County, Washington }\end{array}$ & Tri-Party Agrecument & FATP & $\begin{array}{l}\text { Public } \\
\text { Involvement }\end{array}$ & $\operatorname{con}$ & $\operatorname{com}$ \\
\hline $\begin{array}{l}\text { Trluparty Agreeant } \\
\text { Updated to the comminity } \\
\text { Rolatione plan }\end{array}$ & Tri-Party Agresment & FATP & $\begin{array}{l}\text { Public } \\
\text { Involvement }\end{array}$ & $\operatorname{con}$ & $\operatorname{con}$ \\
\hline
\end{tabular}


Appendix A. Environmental Restoration (ER) Program Documents.

\begin{tabular}{|c|c|c|c|c|c|}
\hline $\begin{array}{l}\text { Dewment } \\
\text { Pftele or } \\
\text { Description }\end{array}$ & $\begin{array}{l}\text { eouree } \\
\text { Recitremint } \\
\text { Dosument }\end{array}$ & $\begin{array}{l}\text { Oooumint } \\
\text { Yype or } \\
\text { coterom }\end{array}$ & $\begin{array}{l}\text { Orfoinoting/ } \\
\text { Reaponstble } \\
\text { orgentzotion }\end{array}$ & $\begin{array}{l}\text { Interim } \\
\text { Record Kewping } \\
\text { orgentzetion }\end{array}$ & $\begin{array}{l}\text { Record } \\
\text { Copy } \\
\text { Holdur }\end{array}$ \\
\hline $\begin{array}{l}\text { Underaround Injection } \\
\text { Control Progrem Document }\end{array}$ & WHC-CH-7-5 & TED & NEPA/ARTP & NEPA/AEHP & $\mathbf{C F}$ \\
\hline $\begin{array}{l}\text { Underground storege reniks } \\
\text { implementetion plens }\end{array}$ & TEO & TED & DE & Ds & CF \\
\hline Wante contral plene & WHC-CH-7-7/EII 4.3 & Teo & $\begin{array}{l}\text { Proleet } \\
\text { Coord. }\end{array}$ & $\begin{array}{l}\text { Iow } \\
\text { coord. }\end{array}$ & $\begin{array}{l}\text { IDU } \\
\text { coord. }\end{array}$ \\
\hline Wate Hengement pleno & TEO & TOD & TEO & TRD & TOD \\
\hline Work Plann & $\begin{array}{c}\text { OSWER 9355.3-01 } \\
\text { WHC-CH-7-7/EII } 1.9 \\
\text { RCRA }\end{array}$ & FATP & $\begin{array}{c}\text { ERE } \\
\text { (CERCLA) } \\
\text { RCRA } \\
\text { Closures } \\
\text { (RCRA) }\end{array}$ & $\begin{array}{c}\text { ERE } \\
\text { (CERCLA) } \\
\text { RCRA } \\
\text { Closures } \\
\text { (RCRA) }\end{array}$ & CF \\
\hline
\end{tabular}

\section{ACROUYMS}

\begin{tabular}{|c|c|}
\hline 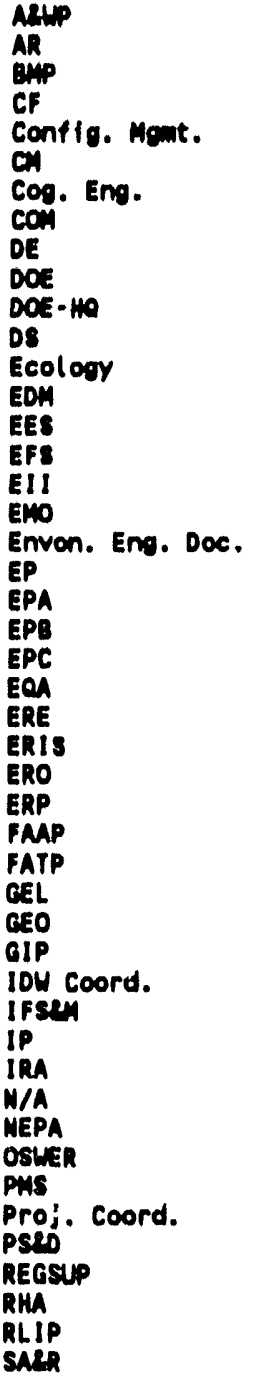 & 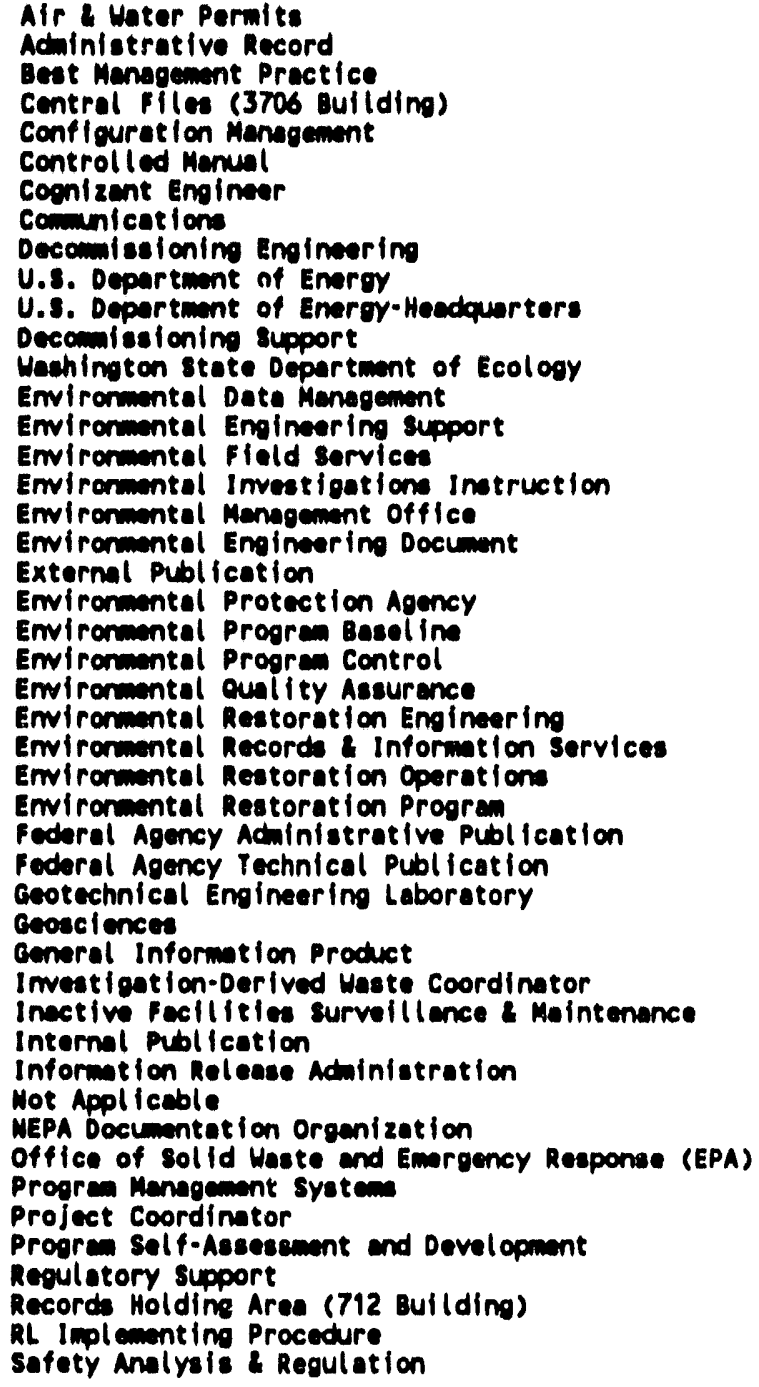 \\
\hline
\end{tabular}




\author{
10 \\ spec. \\ Teo \\ TPA \\ Trl-Porty Aerewment
}

cencla

ain

DOE 6700 .

DOE 5700.80

DOE $5820.2 A$

DOE/RL- $89 \cdot 29$

DOE/RL- $90 \cdot 28$

Rev.1

EN-OARO

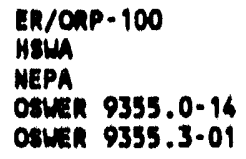

RCRA

RL-TPA-90-0001

$R L-T P A-90-0002$

$R L=T P A-90-0003$

RLIP $4700.1 A$

WMC

WHC-CN-1-6

UHC - CN-3-10

UHC- $\mathrm{CH}-3-5$

WHC-CN-3-6

WHC-CM-4- 46

UHC-CH-6-1

WHC-CN-6-8

WHC - CN-7-5

UHC-CN-7-7

UHC-CM-7-8

WHC-EP-0430, Rev. 1

UHC-EP-0456

WHC-EP-0489-1

WHC-1P-0635 suporting Document

eponaor-Limited Publication

epenclification

To bo Determinud

Trl-Porty Aorement

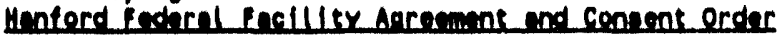

REFERENCE

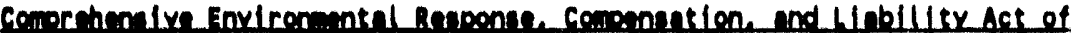
1980

Ctore Hater Aat of 197

U.8. Departiment of Envray Order, mproject Menagement Systeme'

U.s. Department of Eneroy Order, mowall lty Assurance"

hedicect Ive Waste Menagement

Emvironmental Restoration Reandial Action Fleld Offles Management Plan for the Menford site

Emironmentel Restoration oull ty Aseurance syetem Requiremente for the Henford site

DOE Offlce of Emironmental Restoration a Waste Management Quallty Asurence Reoulromente e Dencriotion

Environmental Restoretion Onelte Remadiation Progrem Management Plan

Mazerdowe solld Waste Mandientes of the 1984 United states Code

Metionul Envirommentel Polley Act of 1969

A compendicen of superfund Flold operations Methode

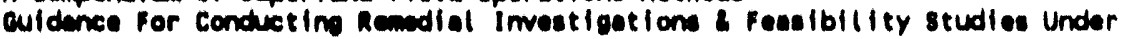
CERCLA

Benource Conmerytion Recoyncy Act of 1976

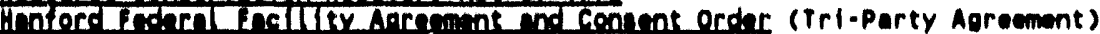
Hencbook

Adtinistrative Record (AR) Indax

Public Informetion Repos l tory Hendbook (PIR-HB)

U.S. Departiment of Energy Hichland Fleld Office RL Implementing Procedure, uproject Management syotement

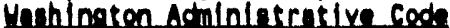

WHC Redologleal Control Menual

software Prectices

Document Control \& Rocords Menagement Menual

Uniform publicetions syetem

Monreactor Facilley safoty Analysle Manual

stendard Enolneering Practlces

Menford Restoration Operation Administration

Environmentel compl lence

Emironomtel Imvetigation site Charecterizetion Manul

emvironmentel enoimering asetechnology Function Procedures

Emironmental Restoration Progrea Records Menagement Plen

Henford Past-prectice sl te Cleenup \& Restoration Conceptual study

Menford slte surfece soll Redianctive Contemination Control Plan for flecal

Year 1903

Ceotechnical Enoineoring Procecturen Menual 
WHC-EP-0433

DISTRIBUTION

Number of copies

OFFSITE

3

V.S. Army Coros of Engineers

District Office

Walla Walla, WA 99362-9265

T. R. Atchison

M. P. Blancq

A5-20

J. T. Stewart

ONSIIE

10

U.S. Department of Energy. Btchland Fleld office

C. E. Clark

A5-15

G. M. Clark

A7-27

J. K. Erickson

R. D. Freeberg

J. D. Goodenough

A5-19

A5-19

R. D. Hudson

R. D. Izatt

R. K. Stewart

N. A. Werdel

RL Public Reading Room

A5-19

A5-19

A3-42

A5-19

A5-19

Al-65

2 Pacific Northwest Laboratory

W. R. Wtley

$K 1-46$

PNL Technical files

$\mathrm{K} 1-11$

1 Kaiser Engineers Hanford

R. T. French

E6-61

Hestinghouse Hanford Company

M. R. Adams

H6-01

W. C. Alaconts

H6-28

B. A. Aust in

D. R. Baker

J. R. Bell

T. L. Bennington

H. L. Benny

G. T. Berlin

J. S. Bishop

J. L. Black

R. M. Boger

B2-35

$X 7-02$

R3-09

H4-16

L7-09

LO-18

H6-07

H6-28

L4-90 
WHC-EP-0433

\section{DISTRIBUTION (continued)}

West inghouse Hanford Company

R. C. Bowman

S. R. Briggs

M. K. Britton

L. C. Brown

W. R. Brown

R. C. Brunke

D. L. Cahow

F. T. Calaprist 1

J. W. Cammann

A. S. Carlson

R. A. Carlson

E. R. Carroll

C. C. Chamberla in-Dow

M. D. Connor

R. F. Cote

K. D. Daschke

C. L. Davis

S. P. Desat

J. A. Diediker

W. T. Dixon

J. J. Dortan

H. D. Downey

B. B. Emory

R. H. Engeimann

B. G. Eri andson

D. G. Farwick

J. W. Fassett

J. 1. Feaster

J. G. Field

K. R. Fecht

G. E. Fitzgibbon (2)

R. D. Fox

K. A. Gano

A. P. Goforth

F. T. Green

D. S. Gunnink

M. C. Hagood

P. S. Hale

D. J. Hart

S. K. Hein

G. C. Henckel

R. P. Henckel

J. A. Highl and

R. T. Hirano

B. J. Hobbs

A. G. Hoffman

D. G. Horton

M. C. Hughes
H6-24

G6-47

B4-54

H6-20

H6-30

H6-23

T2-04

B2-35

H4-14

B3-35

H6-03

A3-74

H6-28

L4-89

H6-28

L4-74

B5-04

H5-25

H6-29

B2-17

H6-20

H6-27

$\times 3-70$

H6-26

H6-20

H4-16

H6-06

H6-06

G2-02

H6-06

H6-07

H6-07

$\times 0-21$

N3-05

H6-30

T1-25

H6-04

B3-35

R3-54

H6-08

H6-04

H6-02

A3-90

B5-25

N3-06

L4-89

H6-06

R2-81 


\section{DISTRIBUTION (continued)}

West inghouse Hanford Company

J. A. Hunter

T. G. Ibsen

D. A. Isom

G. W. Jackson

R. L. Jackson

J. R. Jewett

W. L. Johnson

K. N. Jordan

S. M. Joyce

D. G. Kachele

N. R. Kerr

J. M. Kler

A. J. Knepp

G. H. Landeen

R. J. Landon

M. J. Lauterbach

R. E. Lerch

R. D. Lichfield

A. W. LIIly

L. L. Lockrem

W. C. Mallory

R. P. Marshall

B. M. Martin

M. M. McCarthy

B. H. McGlllicuddy

L5-31

T7-26

H6-08

H6-21

H6-06

T6-09

H6-04

H6-28.

H|-61

S4-67

H4-67

H4-19

H6-06

H6-23

H6-22

H6-01

B3-63

L6-51

TI-05

S3-90

L8-16

T6-04

B5-04

N3-13

H. E. McGutre

$51-54$

B3-63

C. A. Medema

L. E. Michael

H6-08

M. A. Mihalic

P. D. Mix

D. J. Moak

L. M. Montgomery (15)

H6-08

R2-77

H6-29

N3-05

H6-08

H4-19

R2-77

Morton

L6-13

H6-27

J. K. Patterson

H4-23

K. N. Pool

C. N. Potter

B5-04

S. M. Price

W. H. Price

H6-23

N3-05

R. J. Puigh, III

L5-60

J. A. Rawlins

J. G. Reder

HO-36

R. N. Richardson (2)

L4-89

D. M. Robarge

H6-08

R. C. Roos

R2-77

F. A. Ruck

H6-04

H6-23

D. R. Schell

H6-06 

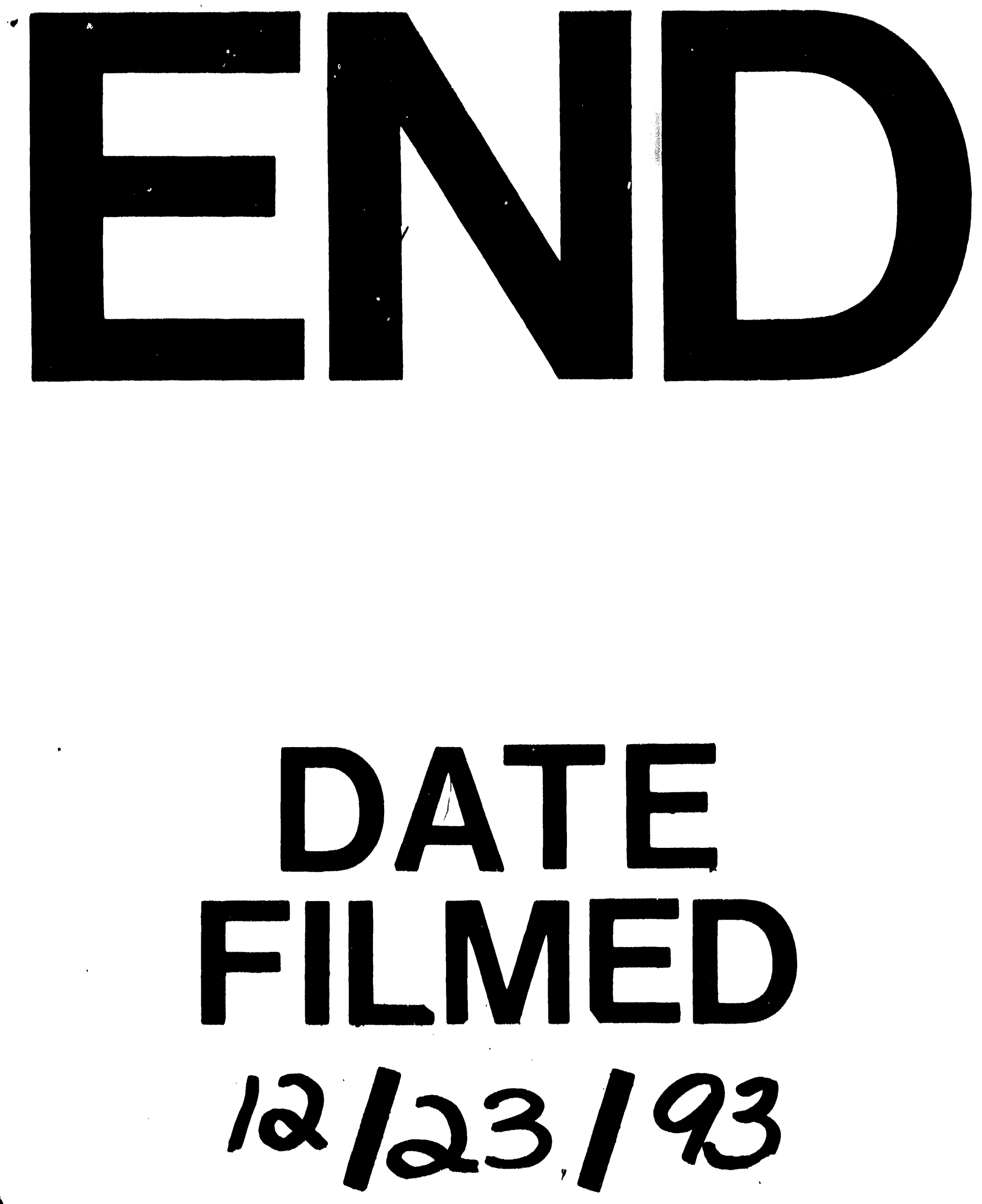

$\Lambda$ 